\title{
Meiotic cell cycle progression requires adaptation to a constitutive DNA damage signal
}

\author{
Liangyu Zhang ${ }^{1,2,3,4}$, Weston T. Stauffer ${ }^{2,6}$, Andrew Ziesel ${ }^{5}$, John S. Wang ${ }^{1}$, \\ Zhouliang $\mathrm{Yu}^{1,2,3,4}$, Nancy M. Hollingsworth ${ }^{5}$, and Abby F. Dernburg ${ }^{1,2,3,4 *}$
}

\begin{abstract}
Affiliations:
${ }^{1}$ Department of Molecular and Cell Biology, University of California, Berkeley, Berkeley, CA 94720-3220, USA

${ }^{2}$ Howard Hughes Medical Institute, 4000 Jones Bridge Road, Chevy Chase, MD 20815, USA

${ }^{3}$ Biological Systems and Engineering Division, Lawrence Berkeley National Laboratory, Berkeley, CA 94720, USA

${ }^{4}$ California Institute for Quantitative Biosciences, Berkeley, CA 94720, USA

${ }^{5}$ Department of Biochemistry and Cell Biology, Stony Brook University, Stony Brook, NY 11794, USA

${ }^{6}$ Department of Integrative Biology, University of California, Berkeley, Berkeley, CA 94720, USA.
\end{abstract}

*Correspondence: afdernburg@berkeley.edu

Running title: Checkpoint adaptation enables meiotic progression 


\begin{abstract}
Meiotic chromosome segregation relies on synapsis and crossover recombination between homologous chromosomes. These processes require multiple steps that are coordinated by the meiotic cell cycle and monitored by surveillance mechanisms. In the nematode Caenorhabditis elegans, CHK-2 kinase is activated at meiotic entry; its activity is essential for homologous synapsis and DSB formation. CHK-2 is normally inactivated at mid-prophase, but how this occurs has not been established. Defects in synapsis or establishment of crossover intermediates delay meiotic progression by prolonging the activity of CHK-2. We report that $\mathrm{CHK}-2$ is necessary and sufficient to inhibit crossover designation. We further find that CHK-2 is inactivated at mid-prophase by a pathway that mediates DNA damage checkpoint adaptation in proliferating human cells: Polo-like kinases, particularly PLK-2, phosphorylate and inhibit CHK-2 in response to formation of crossover intermediates. These findings help to illuminate the mechanisms of crossover assurance and meiotic cell cycle control.
\end{abstract}

\title{
KEYWORDS
}

Meiosis, DNA damage response, Checkpoint adaptation, Recombination, Crossover assurance, Checkpoint kinase, Polo-like kinase, Cell cycle. 


\section{INTRODUCTION}

Meiotic progression differs in many ways from a mitotic cell cycle. A single round of DNA replication at meiotic entry is followed by two nuclear divisions. Between replication and the first division is an extended period known as meiotic prophase, during which chromosomes pair, synapse, and recombine to establish physical links (chiasmata) between each pair of homologs. Together with sister chromatid cohesion, chiasmata direct bipolar chromosome orientation and segregation during Meiosis I (Reviewed in Page and Hawley, 2003; and Petronczki et al., 2003).

How the meiotic regulatory network controls and coordinates the intricate set of steps required to recombine and segregate homologs is only partially understood. Canonical cell cycle regulators such as cyclin-dependent kinases are important (Reviewed in MacKenzie and Lacefield, 2020; Ortega et al., 2003; Wijnker et al., 2019), but many other players are also involved. For example, signaling pathways that are activated in response to DNA damage in proliferating cells are rewired during meiosis to regulate the formation and repair of double strand breaks (DSBs) (Reviewed in Baudat et al., 2013; and Keeney et al., 2014).

Meiotic progression is easily visualized in $C$. elegans due to the simple organization of the germline (Figure S1A). Cells enter meiosis in the distal "arms" of the gonad and move proximally towards the spermatheca and uterus. Homolog pairing and synapsis and DSB induction occur during the first few hours following meiotic entry, in the "transition zone" region corresponding to leptotene and zygotene. The kinase CHK-2 is activated at meiotic entry. It promotes homolog pairing and synapsis by phosphorylating a family of proteins that bind to chromosome regions known as Pairing Centers (Kim et al., 2015), which interact with the nuclear envelope (NE) (Phillips and Dernburg, 2006; Phillips et al., 2005). This primes the recruitment of another kinase, PLK-2, by creating a Polo-box binding motif (Kim et al., 2015). Together CHK-2 and PLK-2 bound to Pairing Centers modify NE proteins including lamin (LMN-1) and the LINC protein SUN-1 to mobilize chromosomes and regulate synapsis (Link et al., 2018; Woglar et al., 2013). CHK-2 is also required for the surveillance of synapsis (Castellano-Pozo et al., 2020). A phospho-specific antibody raised against the consensus CHK-2 target sites on HIM-8 and the ZIM proteins enables cytological detection of CHK-2 activity at Pairing Centers (Kim et al., 2015).

CHK-2 is also essential for DSB induction (MacQueen and Villeneuve, 2001; Oishi et al., 2001). The pathway that promotes breaks in C. elegans is only partially understood, but two 
related proteins known as DSB-1 and DSB-2 depend on CHK-2 activity for their localization to chromatin (Rosu et al., 2013; Stamper et al., 2013). DSBs then recruit a cascade of recombination proteins that mediate their resection and repair through homologous recombination. At mid-pachytene, most of the early recombination intermediates disappear, and six bright designated crossover (CO) foci marked with COSA-1 and other pro-CO factors are detected, one per chromosome pair (Figures 1A, 1B and Figure S1B) (Yokoo et al., 2012). This coincides with the disappearance of CHK-2 activity from Pairing Centers (Kim et al., 2015).

Kinases similar to CHK-2 called Mek1 are required during early meiosis in budding and fission yeasts (Reviewed in Hollingsworth and Gaglione, 2019; and Pérez-Hidalgo et al., 2003). However, Mek1 in budding yeast is activated downstream of DSB induction, rather than being required for DSBs like CHK-2 in C. elegans. Persistent unrepaired DSBs result in prolonged Mek1 activity, which delays meiotic progression (Reviewed in Hollingsworth and Gaglione, 2019).

Meiotic progression is controlled by checkpoints that surveil events unique to meiotic prophase, including synapsis between homologous chromosomes and the formation and resolution of DSBs. In C. elegans, defects in synapsis or the absence of factors required to establish "crossover-competent" intermediates on all chromosomes results in a cell cycle delay (Reviewed in Yu et al., 2016). Activation of the "crossover assurance checkpoint" results in prolonged CHK-2 activity and a delay in the appearance of designated crossover sites (Rosu et al., 2013; Stamper et al., 2013; Woglar and Villeneuve, 2018; Zhang et al., 2018). This checkpoint requires several HORMA-domain proteins that localize along the chromosome axis. These proteins are thought to monitor the progression of synapsis and/or recombination and to promote CHK-2 activity (Kim et al., 2015). In budding yeast, Mek1 is activated through trans-autophosphorylation promoted by its binding to the HORMA domain protein Hop1 (Carballo et al., 2008; Niu et al., 2007). A similar mechanism may contribute to maintaining $\mathrm{CHK}-2$ activity in $C$. elegans.

Here we report that CHK-2 activity is necessary and sufficient to inhibit CO designation during meiotic prophase. We further find that CHK-2 is normally inactivated at midpachytene via inhibitory phosphorylation by PLK-2, which likely prevents substrate binding and also destabilizes the CHK-2 protein. These findings show that a key transition during the meiotic cell cycle occurs through adaptation to a constitutive DNA damage response pathway that is activated at meiotic entry. This work also illustrates how cell cycle kinases can switch 
from acting in concert to antagonizing each other, and further clarifies the signaling network that coordinates chromosome dynamics, DSB formation, and recombination during meiotic prophase.

\section{RESULTS}

\section{CHK-2 inhibits CO designation}

As described above, a key transition normally occurs during mid-pachytene in $C$. elegans oocytes, when CHK-2 activity disappears and foci that correspond to designated crossover sites appear (Figures $1 \mathrm{~A}$ and $1 \mathrm{~B}$ ). Both CHK-2 inactivation and the appearance of designated $\mathrm{CO}$ sites are delayed in mutants that activate the crossover assurance checkpoint. Thus, we wondered whether CHK-2 activity directly inhibits $\mathrm{CO}$ designation. Because CHK-2 activity during early meiotic prophase is essential for DSB formation and synapsis (MacQueen and Villeneuve, 2001; Oishi et al., 2001), and thus for the establishment of intermediates that are prerequisite for $\mathrm{CO}$ designation, we exploited the auxin inducible degradation (AID) system to deplete CHK-2 activity (Nishimura et al., 2009; Zhang et al., 2015). The activity of degrontagged CHK-2 became undetectable in meiotic nuclei within 3 hours of auxin treatment (Figure S1C). Depletion of CHK-2 shifted the appearance of nuclei containing six bright COSA-1 foci to a more distal (earlier) position in the germline, indicative of accelerated CO designation (Figures $1 \mathrm{C}, 1 \mathrm{E}$ and $1 \mathrm{~F}$ ).

We reasoned that if $\mathrm{CO}$ designation is inhibited by CHK-2, then depletion of CHK-2 should be sufficient to "rescue" earlier designation in mutants that disrupt establishment of CO intermediates on a subset of chromosomes. We depleted CHK-2 in him-8 and him-5 mutants, which specifically affect synapsis or DSB induction, respectively, on the $\mathrm{X}$ chromosomes, but do not impair CO formation on autosomes (Broverman and Meneely, 1994; Hodgkin et al., 1979; Meneely et al., 2012; Phillips et al., 2005). In each case we observed a shift in the appearance of bright COSA-1 foci towards the distal region of meiotic prophase following CHK-2 depletion (Figures 1D and 1G; Figures S1D-S1G). This result reinforces evidence described above that $\mathrm{CHK}-2$ activity is both necessary and sufficient to delay CO designation in response to feedback regulation.

We observed some differences between the two mutants: in him-8 mutants RAD-51 was far more abundant in the extended region of CHK-2 activity, and persisted even after CHK-2 was depleted, resulting in the appearance of nuclei with both RAD-51 foci and bright COSA- 
1 foci. In contrast, RAD-51 foci were sparser in him-5 and mostly disappeared upon CHK-2 depletion (Figures S1D-S1G). These differences likely reflect the different arrest points of the two mutants: him- 8 oocytes arrest at a zygotene-like state with high CHK-2 activity, while him-5 mutants arrest at an "early-pachytene-like" state with an intermediate level of CHK-2 activity (Kim et al., 2015). We speculate that progression to early pachytene and the associated reduction in CHK-2 activity in him-5 mutants may attenuate break formation and/or allow breaks to progress to a more advanced stage of repair, so that upon CHK-2 depletion they are more rapidly resolved.

\section{Polo-like kinases inactivate $\mathrm{CHK}-2$ to promote timely $\mathrm{CO}$ designation}

A key unanswered question is how CHK-2 is normally inactivated at mid-prophase to terminate DSB induction and promote CO designation. Prior work on inactivation of DNA damage response (DDR) signaling in proliferating cells revealed that the Polo-like kinase Plk1 enables mammalian cells to enter mitosis following DDR activation by phosphorylating the FHA domain of Chk2, which inhibits substrate binding (Vugt et al., 2010). We wondered whether a similar mechanism might regulate $\mathrm{CHK}-2$ in meiosis.

C. elegans expresses multiple homologs of mammalian Plk1, including PLK-1, which is essential for mitosis, and PLK-2, which plays important roles in meiosis (Chase et al., 2000; Harper et al., 2011; Labella et al., 2011). Loss of plk-2 perturbs pairing and synapsis, and also causes a pronounced delay in $\mathrm{CO}$ designation and chromosome remodeling during late prophase (Harper et al., 2011; Labella et al., 2011). To test whether C. elegans CHK-2 might be a substrate of PLK-2, we performed in vitro phosphorylation assays using purified PLK-2 and a CHK-2 ${ }^{\mathrm{KD}}$ (kinase dead) substrate, to avoid potential autophosphorylation of CHK-2. Mass spectrometry identified threonine 120 in the FHA domain of CHK-2 as an in vitro target of PLK-2 (Figure 2A). Alignment of the sequence around Thr120 on CHK-2 orthologs from yeast to human reveals that this site is highly conserved (Figures $2 \mathrm{~B}$ and $2 \mathrm{C}$ ). It is also close to serine 116, which corresponds to one of the Chk2 sites phosphorylated by Plk1 in human cells (Vugt et al., 2010). S116 and T120 both conform to the loose consensus motif shared by Plk1 substrates (Figure 2B) (Santamaria et al., 2011). These results indicated that PLK-2 might phosphorylate and inactivate CHK-2 during meiosis.

As described above, during early meiotic prophase CHK-2 and PLK-2 work together at Pairing Centers to promote homolog pairing and synapsis. Upon completion of synapsis, PLK-2 is recruited to the synaptonemal complex (SC) by a Polo box binding motif on SYP-1 
(Sato-Carlton et al., 2017). Following CO designation at mid-pachytene, PLK-2 activity can be detected along the "short arm" of the chromosomes (Ferrandiz et al., 2018; Sato-Carlton et al., 2017). In plk-2 null mutants, PLK-1 can partially substitute for PLK-2 at Pairing Centers to promote pairing and synapsis, but crossover designation and subsequent chromosome remodeling are markedly delayed (Harper et al., 2011; Labella et al., 2011; Sato-Carlton et al., 2017, 2020).

To determine whether PLK-2 is important for meiotic progression independent of its role in promoting synapsis, we depleted the protein using the AID system. Exposure of animals carrying degron-tagged PLK-2 to auxin for as little as a few hours was sufficient to delay CHK-2 inactivation and CO designation (Figures 2D, 2F and data not shown). We reasoned that if PLK-2 promotes timely $\mathrm{CO}$ designation by inactivating $\mathrm{CHK}-2$, then the late $\mathrm{CO}$ designation observed in plk-2 mutants should be rescued by AID-mediated depletion of CHK-2. Indeed, we found that depletion of CHK-2 restored earlier CO designation in plk-2 null mutants (Figures $2 \mathrm{E}$ and $2 \mathrm{G}$ ).

We attempted to test the role of CHK-2 phosphorylation on S116 and/or T120 by mutating these sites to nonphosphorylatable and phosphomimetic residues. Surprisingly, these mutations all led to loss of CHK-2 function, and to a dramatic reduction in CHK-2 protein levels; only S116A was partially functional (Figure $2 \mathrm{H}$ ). These mutations all behaved recessively in heterozygotes, indicating that the loss of CHK-2 is not due to gene silencing, which would be expected to act in trans (Dernburg et al., 2000).

We wondered how CHK-2 might be negatively regulated by PLK-2 at mid-pachytene, given that PLK-2 does not inhibit CHK-2 during the leptotene/zygotene stage, when both are bound to Pairing Centers. We speculated that recruitment of PLK-2 to the SC may activate it towards CHK-2 as a substrate. To test this idea, we examined CHK-2 activity and its protein levels in syp-1 ${ }^{T 452 A}$ mutants, which lack the Polo-box binding motif (S-pT-P) that recruits Polo kinases to the SC (Sato-Carlton et al., 2017). Consistent with prior analysis, this single point mutation delayed crossover designation (Sato-Carlton et al., 2017; Figures 3A and 3B). Moreover, CHK-2 protein was more abundant and its activity was extended in $s y p-1^{T 452 A}$ mutants (Figures 3A-3D). CHK-2 depletion also restored earlier CO designation in syp-1 $1^{T 452 A}$ mutants, as in plk-2 mutants (Figures $3 \mathrm{E}$ and $3 \mathrm{~F}$ ), Thus, binding of PLK-2 to the SC is important for downregulation of CHK-2, and conversely, the delay in CO designation in syp$1^{T 452 A}$ mutants is a direct consequence of persistent CHK-2 activity. 
Although mutation or depletion of PLK-2 or failure to recruit it to the SC delayed inactivation of CHK-2, this delay was eventually bypassed, since markers for CHK-2 activity disappeared and CO designation occurred. Thus, we wondered how CHK-2 becomes inactivated in the absence of PLK-2. We tested whether PLK-1 might compensate for loss of PLK-2, as it does during early meiosis, by co-depleting both Polo-like kinases (Figure S2A). Compared to PLK-2 depletion alone, CO designation was further delayed when PLK-1 and PLK-2 were both depleted, indicating that PLK-1 can contribute to CHK-2 inactivation during late prophase (Figures 2D and 2F; Figures S2B and S2C).

The ERK kinase MPK-1 promotes pachytene exit and has been proposed to contribute to crossover designation (Hayashi et al., 2007; Nadarajan et al., 2016; Church et al., 1995; Lee et al., 2007). We used the AID system to test whether MPK-1 promotes CHK-2 inactivation or crossover designation. MPK-1::AID was undetectable in germline cells following 1 hour of auxin treatment (Figure S3A). Although depletion of MPK-1 led to a disordered appearance of the proximal germline, it did not cause any apparent delay in $\mathrm{CO}$ designation, either alone or in combination with $s y p-1^{T 452 A}$ (Figures S3B-S3E). We speculate that a rise in CDK activity and/or other spatially regulated signals in the proximal gonad may lead to CHK-2 inactivation even when PLK activity is absent.

In yeast, the Polo-like kinase Cdc5 is required for SC disassembly, joint molecule resolution to generate crossovers, and Mek1 inactivation (Clyne et al., 2003; Prugar et al., 2017; Sourirajan and Lichten, 2008). When Cdc5 was depleted from meiotic cells by replacing its promoter with the mitosis-specific $C L B 2$ promoter ( $c d c 5-m d)$, the SC proteins Red1 and Zip1 persisted, despite the fact that $\mathrm{Ndt} 80$, the meiosis-specific transcription factor necessary for exit from pachynema, was active and metaphase spindles were formed (Figures S4A, S4B and S4E) (Clyne et al., 2003). In addition, Mek1protein accumulated to higher levels than in wild-type cells and Mek1 activity, as indicated by the presence of phosphorylated Hed1, persisted, as expected if $C D C 5$ is required for Mek1 inactivation (Figure S4A). These findings led us to test whether Cdc5 first inactivates Mek1, which then allows SC protein degradation, or instead whether the destruction of the SC mediated by Cdc5 inactivates Mek1. While depletion of CHK-2 was sufficient to promote CO designation in C. elegans, inhibition of Mek1 in yeast, either immediately after meiotic induction or at 6 hours after entry into prophase, was not sufficient to bypass the requirement for Cdc5 in timely SC degradation and CO formation (Figures S4C and S4D), indicating that Cdc5 is important for SC degradation and joint molecule resolution independently of Mek1 activity. This difference may reflect the dependence of late meiotic events in yeast on a gene expression 
program driven by the transcription factor $\mathrm{Ndt80}$ (Xu et al., 1995). There has been no evidence for transcriptional induction of "late" meiotic genes in C. elegans, so meiotic progression may rely more heavily on posttranslational regulation in the syncytial germline.

We also tested whether Mek1 S91 or T95, which correspond to residues that downregulate Chk2/CHK-2 when phosphorylated (Figure 2B), are important in $S$. cerevisiae meiosis. Unfortunately, we found that these mutants behaved as nulls and led to spore inviability (Figure S4C), very similar to the effects of the corresponding mutants in C. elegans. As $C$. elegans S116, T95 tolerated mutation to alanine (Figure S4C), but this did not markedly perturb meiosis. Thus, we could not determine whether this pathway regulates Mek1 activity during meiosis.

\section{DISCUSSION}

In most eukaryotes, attaining at least one crossover (crossover assurance) between every pair of homologous chromosomes is essential for accurate meiotic chromosome segregation (Page and Hawley, 2003). In organisms where synapsis depends on the formation of interhomolog joint molecules through the "ZMM" pathway, as in budding yeast, cells may monitor synapsis as a proxy for the presence of CO-competent intermediates. In $C$. elegans, complete synapsis can occur in the absence of recombination intermediates, and meiocytes surveil both synapsis and $\mathrm{CO}$ precursors to ensure chiasma formation and faithful segregation (reviewed in Yu et al., 2016). CHK-2 inactivation - and thus meiotic progression - is delayed in response to defects in synapsis or formation of CO-competent intermediates (CastellanoPozo et al., 2020; Kim et al., 2015). These checkpoints depend on a common set of factors, including four axis-associated HORMA proteins (HIM-3, HTP-1, HTP-2, and HTP-3) (Castellano-Pozo et al., 2020; Kim et al., 2015). In many organisms HORMA domain proteins are removed from axes as homologs synapse, but in $C$. elegans these proteins remain associated with synapsed chromosomes until late pachytene (Goodyer et al., 2008; MartinezPerez et al., 2008; Zetka et al., 1999). It is not yet clear how the HORMA domain proteins sense the presence or absence of $\mathrm{CO}$ intermediates, but we speculate that a signal may be transduced through the SC.

Although PLK-2 is recruited to the SC starting in early pachytene (Harper et al., 2011; Labella et al., 2011), this localization is not sufficient to inactivate CHK-2. PLK-2 target sites on the axis protein HIM-3 (Sato-Carlton et al., 2020) and the central region protein SYP-4 (Nadarajan et al., 2017) are not detectably phosphorylated until after the establishment of CO 
intermediates on all chromosomes. Together this evidence suggests that $\mathrm{CO}$ intermediates somehow activate Polo-like kinases along SCs, leading to CHK-2 inactivation and silencing of the crossover assurance checkpoint. Notably, functional Pairing Centers are also required to delay CHK-2 inactivation, although CHK-2 can be activated even in the absence of Pairing Centers (Kim et al., 2015).

In budding yeast, activation of the sole Polo-like kinase Cdc5 also triggers the inactivation of checkpoint protein Mek1 to promote recombination checkpoint recovery in meiosis (Reviewed in Hollingsworth and Gaglione, 2019; Matos et al., 2011; Prugar et al., 2017; Sourirajan and Lichten, 2008). However, our experiments to determine whether Cdc5 directly inactivates Mek1 have been inconclusive. In mouse spermatocytes, PLK1 localizes along the SC and is required for pachytene exit (Jordan et al., 2012), suggestive of a more direct parallel to the circuit we have elucidated in $C$. elegans.

In C. elegans, CHK-2 and PLK-2 work cooperatively at Pairing Centers to mediate homolog pairing and synapsis. They are recruited by the Pairing Center proteins HIM-8 and ZIM-1, 2, and -3, each of which contain 1-2 modules with adjacent FHA-binding and Polo-boxbinding motifs (Harper et al., 2011; Kim et al., 2015; Labella et al., 2011). Our evidence that PLK-2 antagonizes the activity of CHK-2 to enable meiotic progression raises the question of how CHK-2 is shielded from inhibition by PLK-2 during early meiosis. We suggest two possible explanations: 1) Binding of CHK-2 to the Pairing Center proteins may occlude the sites on its FHA domain, protecting it from inhibitory phosphorylation, and/or 2) the specificity of PLK-2 may be altered by binding to the SC and/or the formation of CO precursors. Interestingly, Caenorhabditis also express a unique meiotic regulator of PLK-2 activity, HAL-2/HAL-3, which is required to sustain CHK-2 activity during early prophase (Roelens et al., 2019; Zhang et al., 2012). This activity may have evolved to enable CHK-2 and PLK-2 to work in concert during early meiosis.

\section{ACKNOWLEDGEMENTS}

This work was supported by funding from the National Institutes of Health (R01 GM065591 to AFD and GM050717 to NMH), the Howard Hughes Medical Institute to AFD and a generous donation from Eugene and Carol Cheng to NMH. Some strains were provided by the Caenorhabditis Genetics Center (CGC), which is funded by NIH Office of Research Infrastructure Programs (P40 OD010440). We thank Yumi Kim for sharing the PLK-2 and 
CHK-2 plasmids, Lihong Wan for technical help and members of the Dernburg lab for helpful discussions throughout this work and for critical reading of the manuscript.

\section{AUTHOR CONTRIBUTIONS}

Conceptualization, L.Z. and A.F.D.; Methodology, L.Z., A.Z., N.M.H. and A.F.D.;

Investigation, L.Z., A.Z., J.S.W., Z.Y., W.T.S., N.M.H. and A.F.D.; Writing-original draft, L.Z.; Writing—review and editing, L.Z., A.Z., N.M.H. and A.F.D.; Funding acquisition, N.M.H. and A.F.D.; Resources, L.Z., A.Z., N.M.H. and A.F.D.; Supervision, N.M.H. and A.F.D.

\section{DECLARATION OF INTERESTS}

The authors declare no competing financial interests.

\section{AUTHOR ORCIDS}

Liangyu Zhang http://orcid.org/0000-0002-2701-0773

Nancy M. Hollingsworth http:// orcid.org/0000-0003-3300-6444

Abby F Dernburg http://orcid.org/0000-0001-8037-1079 
bioRxiv preprint doi: https://doi.org/10.1101/2021.06.20.449183; this version posted June 21, 2021. The copyright holder for this preprint 19. 1 (which was not certified by peer review) is the author/funder. All rights reserved. No reuse allowed without permission.
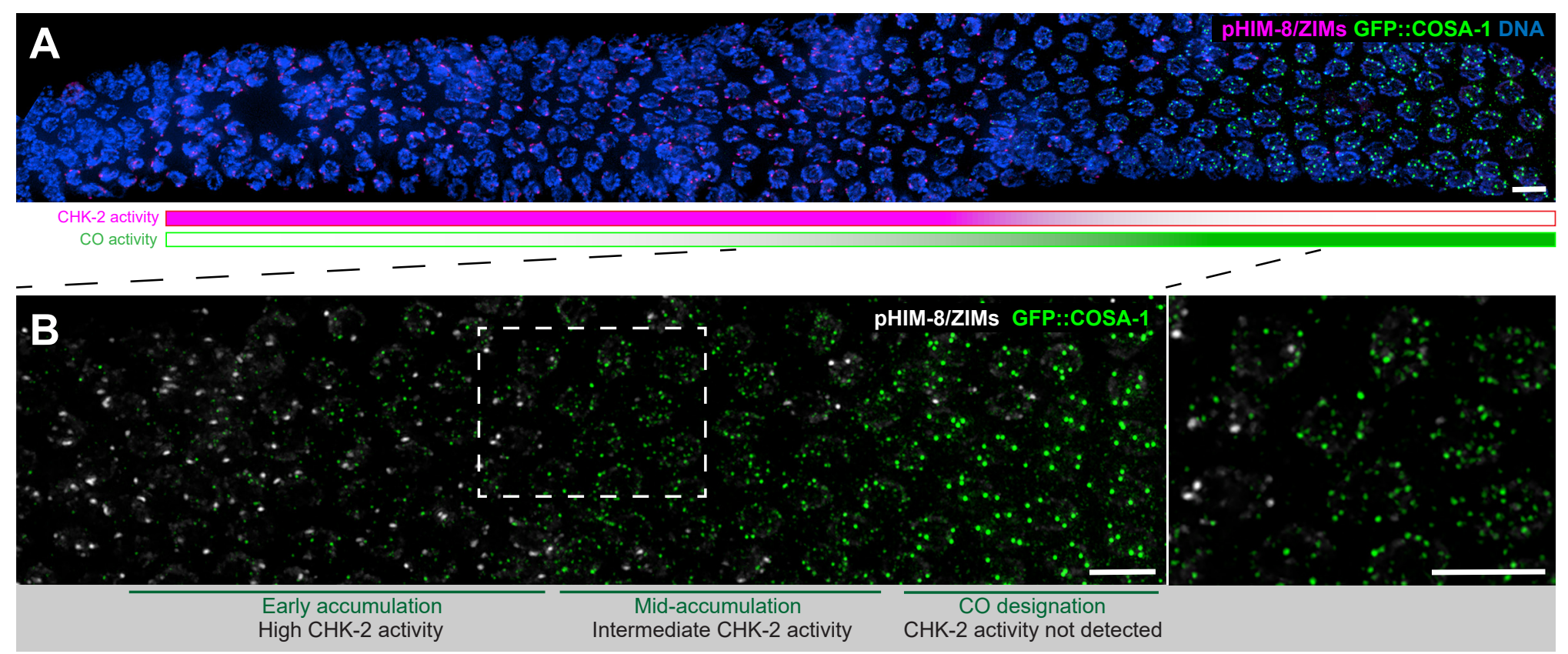

C

-auxin

aid::chk-2

$+\operatorname{auxin} 5 \mathrm{~h}$

GFR::COSA-1 SYP-1 DNA

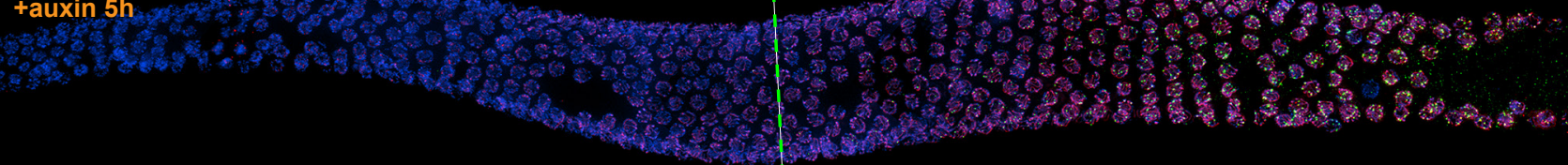

D

-auxin

him-8; aid::chk-2

+auxin $5 \mathrm{~h}$
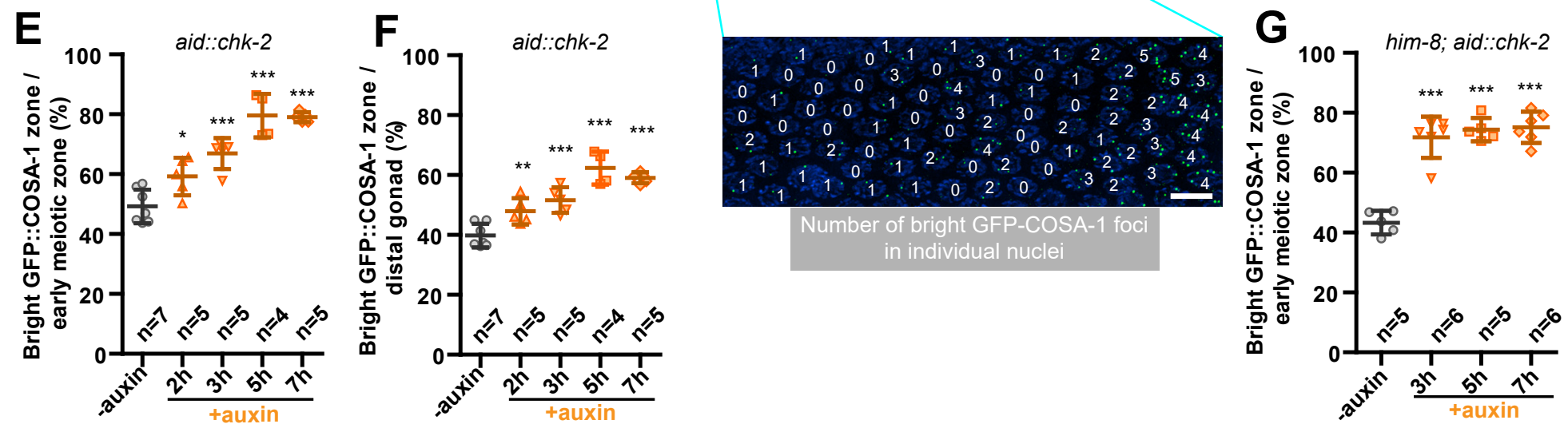


\section{Figure 1. CHK-2 inhibits CO designation activity}

(A) During early prophase, recombination foci positive for pro-CO factors (represented by GFP::COSA-1, green) accumulate in meiotic nuclei as CHK-2 activity at Pairing Centers (indicated by phospho-HIM-8 and -ZIM-1/2/3 (Kim et al., 2015), magenta) decreases. Note: the same image is shown in Figure S1B.

(B) High-magnification images of nuclei at mid-pachytene. Boxed areas indicate nuclei shown at higher magnification on the right. Accumulation of pro-CO proteins can be stratified into three stages: an early stage with high CHK-2 activity and variable numbers of $\operatorname{dim}$ GFP::COSA-1; an intermediate stage with brighter and fewer visible GFP::COSA-1 foci, and a post-designation stage, with a single $\mathrm{CO}$-designated sites per chromosome pair marked by bright GFP::COSA-1 fluorescence. Scale bars, $5 \mu \mathrm{m}$.

(C) Representative hermaphrodite gonads stained for GFP::COSA-1 (green), SYP-1 (red) and DNA (blue). Nuclei with designated COs are observed at a more distal position following CHK-2 depletion. Worms were exposed to $1 \mathrm{mM}$ auxin (or $0.25 \%$ ethanol lacking auxin) for $5 \mathrm{~h}$ before fixation. Dashed green lines indicate the earliest nuclei with designated CO sites and the end of pachytene, respectively. Scale bars, $5 \mu \mathrm{m}$. Note: the same image with RAD-51 is shown in Figure S1D.

(D) Germline from a him-8 hermaphrodite stained for GFP::COSA-1 (green), and DNA (blue), showing early CO designation upon CHK-2 depletion. Worms were treated with 1 $\mathrm{mM}$ auxin or solvent (ethanol) control for $5 \mathrm{~h}$ before analysis. An enlargement showing early pachytene nuclei is shown below. Scale bars, $5 \mu \mathrm{m}$.

(E-F) CO designation occurs earlier upon CHK-2 depletion as described in (C). Worms were exposed to auxin (or solvent control) for 2, 3, 5 or $7 \mathrm{~h}$ before analysis. We define the "designated CO zone" as the length of the region with bright GFP::COSA-1 foci, expressed as a fraction of the length of the region from meiotic onset (E) or the distal tip of the gonad (F) to the end of pachytene, before oocytes form a single row of cells. Meiotic onset was determined by the staining of meiosis-specific proteins SYP-1 and/or HTP-3. $\mathrm{n}=$ number of gonads scored for each condition. ${ }^{*} \mathrm{p}=0.0161$ and ${ }^{* * *} \mathrm{p}=0.0003$, or $<0.0001$ respectively (E), ${ }^{* *} \mathrm{p}=0.007$ and ${ }^{* * *} \mathrm{p}=0.0006$, or $<0.0001$ respectively $(\mathrm{F})$, two-sided Student $t$-test. Since both quantification methods yield the same results, hereafter we express the designated CO zone only relative to the region from meiotic onset to the end of pachytene. 
bioRxiv preprint doi: https://doi.org/10.1101/2021.06.20.449183; this version posted June 21, 2021. The copyright holder for this preprint (which was not certified by peer review) is the author/funder. All rights reserved. No reuse allowed without permission.

(G) Quantitative comparison of the timing of CO designation in worms as described in (D). Worms were treated with or without $1 \mathrm{mM}$ auxin for 3, 5 or $7 \mathrm{~h}$ before analysis.

Quantification was performed as described in (E).

See also Figure S1. 
bjoßxiv preprint doi: https://doi.org/10.1101/2021.06.20.449183; this version posted June 21, 2021. The copyright holder for this preprint Fig. $\mathbf{S 1}$ (which was not certified by peer review) is the author/funder. All rights reserved. No reuse allowed without permission.

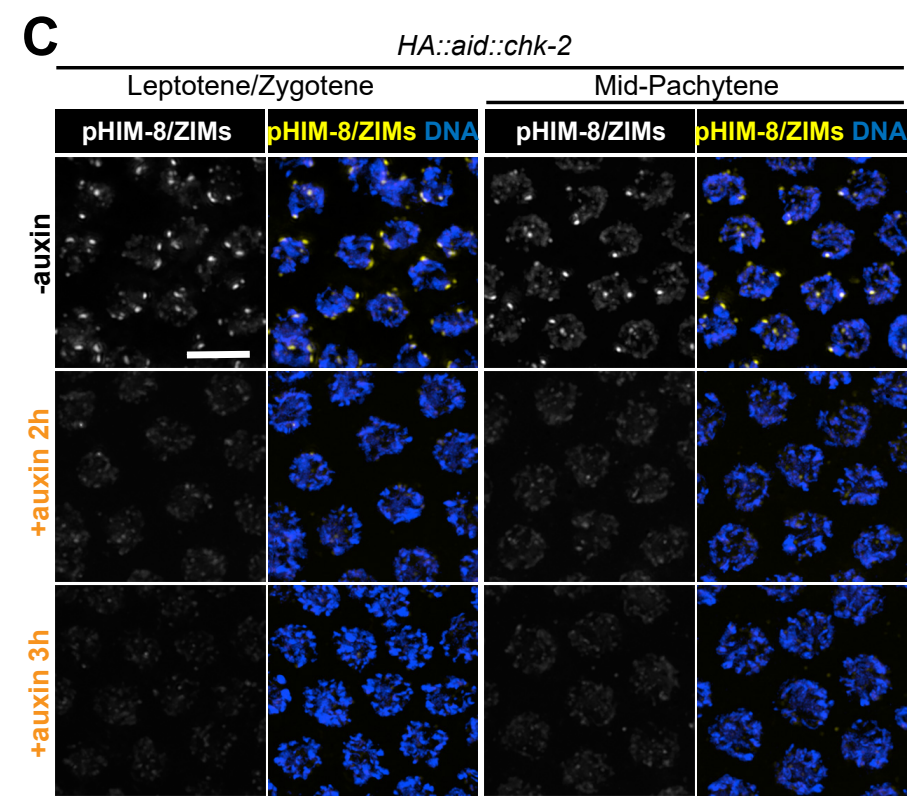

D
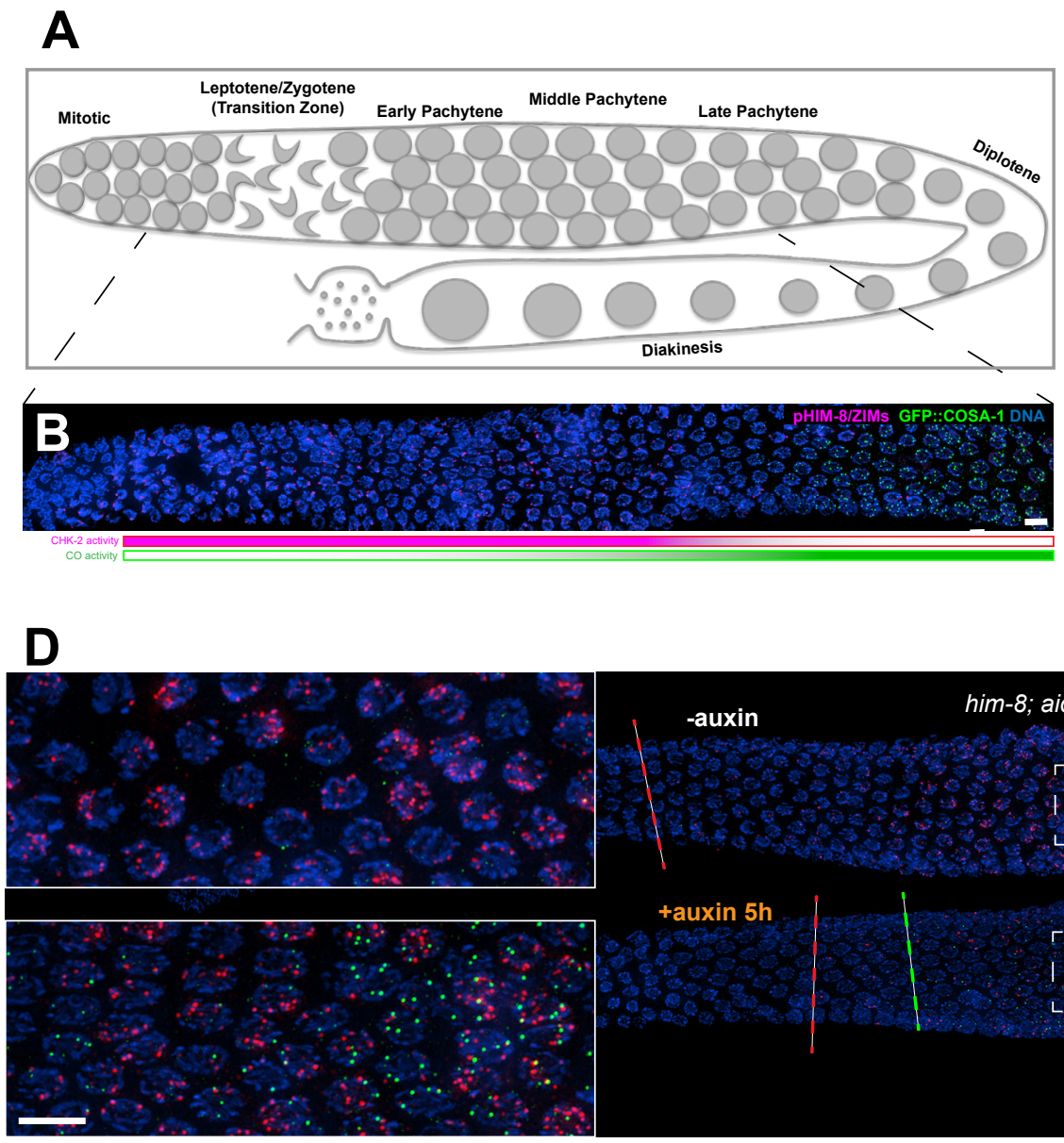

-auxin

tauxin $5 h$ him-8; aid::chk-2

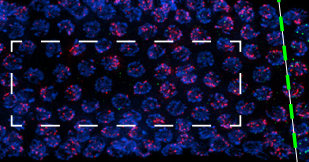

$r-----1$
GFP::COSA-1 RAD-51 DNA

GFP-COSA-1 RAD-51 DNA him-5; aid::chk-2

-auxin

tauxin 5 h

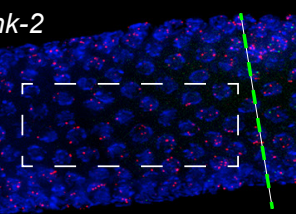

$\therefore$

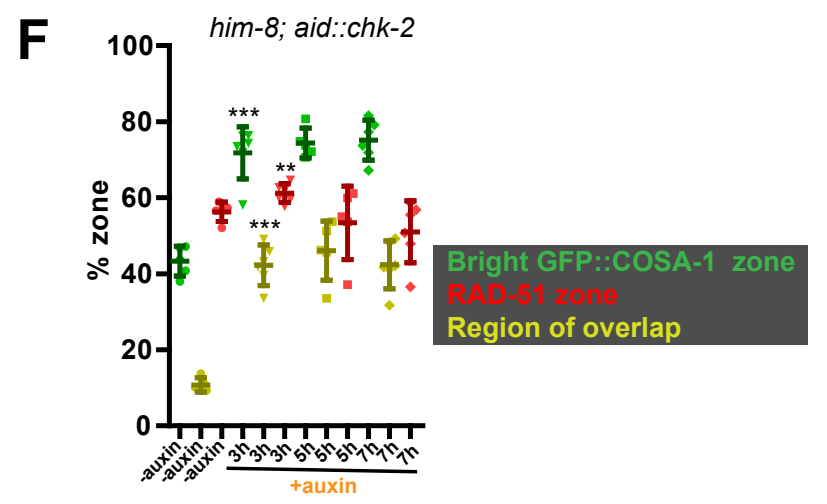

G 1007 him-5; aid::chk-2 
Figure S1. Stages of meiotic prophase in the $C$. elegans germline and conditional depletion of CHK-2 activity, Related to Figure 1.

(A) Schematic of meiotic prophase in the C. elegans hermaphrodite germline.

(B) Images of representative prophase nuclei show the recombination intermediates (indicated by GFP::COSA-1, green) and CHK-2 activity (indicated by phospho-HIM/ZIMs immunofluorescence, magenta). Note: the same image is shown in Figure 1A. Scale bars, 5 $\mu \mathrm{m}$.

(C) Representative leptotene/zygotene and mid-pachytene nuclei stained for phosphorylated HIM-8/ZIMs and DNA, showing efficient depletion of CHK-2 activity in the germline upon auxin treatment. Worms were incubated with $1 \mathrm{mM}$ auxin (or $0.25 \%$ ethanol lacking auxin) for 2, 3, 5 or $7 \mathrm{~h}$ before analysis. CHK-2 activity was undetectable within $3 \mathrm{~h}$ upon auxin treatment. Scale bars, $5 \mu \mathrm{m}$.

(D-E) Representative him-8 (D) or him-5 (E)hermaphrodite gonads stained for GFP::COSA-1 (green), RAD-51 (red) and DNA (blue), revealing earlier CO designation upon CHK-2 depletion. Worms were exposed to $1 \mathrm{mM}$ auxin (or $0.25 \%$ ethanol lacking auxin) for $5 \mathrm{~h}$ before fixation. Green dashed lines indicate where CO designation starts and where pachytene ends, respectively. While, red dashed lines in (D) indicate RAD-51-positive zone. Scale bars, $5 \mu \mathrm{m}$. Note: the same image in (D) without RAD-51 is shown in Figure 1D.

(F-G) Quantitative comparison of the RAD-51-positive zone in him-8 mutants and of CO designation timing upon CHK-2 depletion in him-5. Worms were exposed to auxin for 3, 5 or $7 \mathrm{~h}$ before fixation and analysis. The "designated $\mathrm{CO}$ zone" was defined as the length of the region with bright GFP::COSA-1 foci, expressed as a fraction of the length of the region from meiotic onset to the end of pachytene, before oocytes form a single row. The RAD-51 zone and the region of overlap between the RAD-51 and designated CO zones were measured and expressed in the same way. Meiotic onset was determined by the staining of meiosis-specific proteins SYP-1 and/or HTP-3. ${ }^{* *} \mathrm{p}=0.001$ and ${ }^{* * *} \mathrm{p}<0.0001$ in $(\mathrm{F}),{ }^{*} \mathrm{p}=0.0114$, ${ }^{* *} \mathrm{p}=0.0032$ and 0.0012 in $(\mathrm{G})$, respectively, two-sided Student $t$-test. 


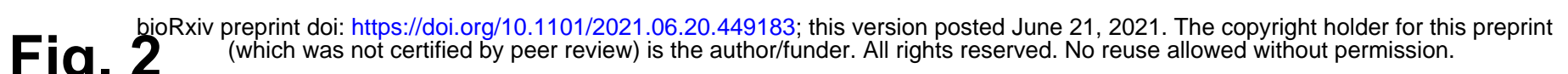

A In vitro phosphorylation followed by Mass Spectrometry

\begin{tabular}{|l|c|c|c|} 
Substrate & Kinase & Coverage & $\begin{array}{c}\text { \# of peptides } \\
\text { containing T120 (pT120) }\end{array}$ \\
\hline CHK-2 & - & $75 \%$ & $9(0)$ \\
\hline CHK-2 $^{\text {KD }}$ & PLK-2 & $74 \%$ & $10(3)$ \\
\hline
\end{tabular}

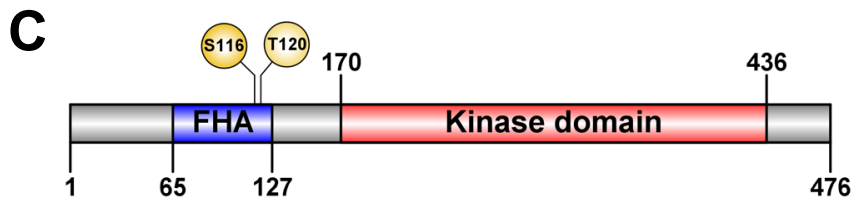

B

Note: peptides with probability $>90 \%$ were scored.

C. elegans CHK-2

S. cerevisiae Mek1

S. cerevisiae Rad53

D. melanogaster Loki

D. rerio Chk2

X. laevis Chk2

M. musculus Chk2

H. sapiens Chk2

99 FSTDR- - -DT-ETR--RIYLHDHSRNGTLVNOEMIGKGLSRELMNGDLISIGI- - - - - P 146

73 WCVFF--D--EDS I PMFYVKDCSLNGTYLNGLLLKRDKTYLLKHCDVIELSOGSEENDI 127

89 FOILL--_G--EDG--NLLLNDISTNGTWLNGOKVEKNSNOLLSOGDEITVGVGVESDIL 141

99 FII KRANCEL- - TN-PVY I QDL SRNGTFVNNGKI GTNRMR I LKNDDVI SLSHPTYKAFV 154 122FRIFR- - D- - EN - - LVYLEDLS GNGTWVDDEKLGNGKOSLLGNNSVI ALAEOKHOVFM 173

116 FR I FQ- - -ELGHGH SRVANIEDLSGNGTFVNKEIIGKGRTLPLTNNAEIALSLPTNKVFV 172

148FR I F R- - -EMG P KN CY I VY I EDHSGNGTF VNTEL I GK GKRC PL SNNSE I ALSLCRNKVF V 204

187FR I FR- - -EVGPKN S Y I IY I DDHSGNGTFVNTELVGKGKRR PLNNNSE I ALSLS RNKVFV 243

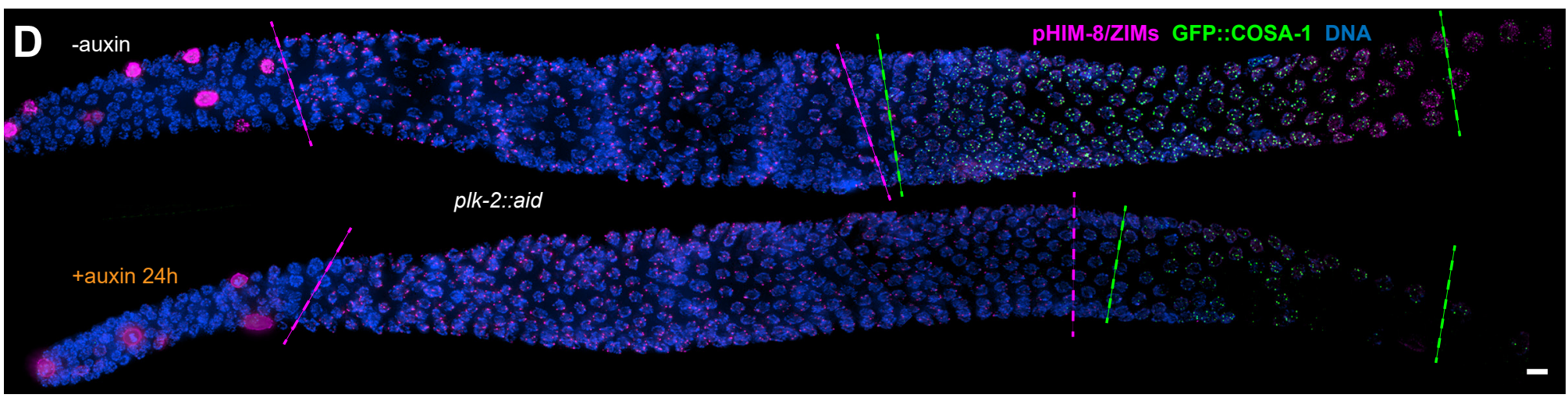

르

-auxin

GFP::COSA-1 DNA

\section{sin}

+auxin 3h

plk-2; aid::chk-2

+ auxin $5 \mathrm{~h}$
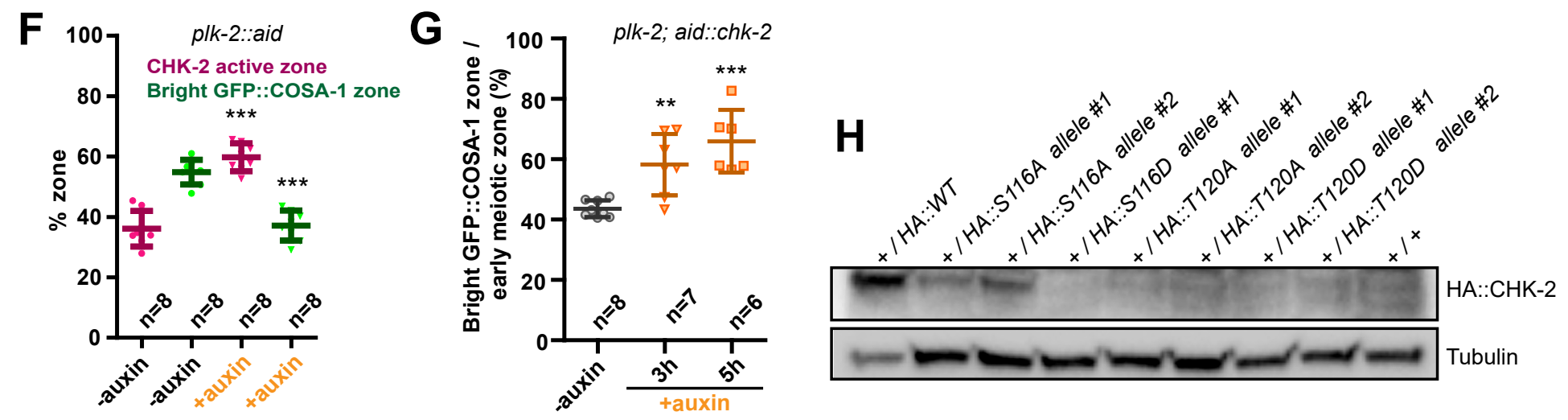


\section{Figure 2. Inactivation of CHK-2 by Polo-like kinases mediates timely CO designation}

(A) Recombinant kinase-dead CHK-2 protein $\left(\mathrm{CHK}-2^{\mathrm{KD}}\right)$ was phosphorylated in vitro by PLK-2 kinase and then subjected to mass spectrometry analysis for phosphorylation site identification. CHK-2 Thr120 was identified as a target of PLK-2.

(B) Sequence alignment of CHK-2 orthologs from various eukaryotes generated with TCoffee (Notredame et al., 2000), showing the conservation of Ser116 (Vugt et al., 2010) and Thr120 (asterisks). Dark and gray shading indicate identical and similar residues, respectively.

(C) Schematic showing the domain organization of CHK-2 protein and the positions of phosphorylation sites. FHA: Forkhead-associated domain. Numbers indicate amino acid positions. C. elegans CHK-2 and budding yeast Mek1 are meiosis-specific kinases that share the FHA and serine/threonine kinase domains of mammalian Chk2 and yeast Rad53, but lack the $\mathrm{N}$-terminal $\mathrm{SQ} / \mathrm{TQ}$ cluster that regulates activation of Chk2 by ATM.

(D) PLK-2 is required for timely CO designation in meiosis. plk-2::aid; $P_{\text {sun-1::tir1 }}$ hermaphrodites were treated with $1 \mathrm{mM}$ auxin for $24 \mathrm{~h}$ and stained for pHIM-8/ZIMs (magenta), GFP::COSA-1 (green) and DNA (blue). Dashed magenta lines indicate the CHK-2 active zone. Green lines indicate the designated CO zone. Scale bars, $5 \mu \mathrm{m}$.

(E) Depletion of CHK-2 restores early crossover designation in plk-2 mutants. Worms were treated with or without $1 \mathrm{mM}$ auxin for 3 or $5 \mathrm{~h}$. Scale bars, $5 \mu \mathrm{m}$.

(F-G) Quantification of the extension of the CHK-2 active zone and delay in CO designation in worms depleted for PLK-2, as described in (D) and of CO designation in plk-2 mutants upon depletion of CHK-2 as described in (E), respectively. $\mathrm{n}$ = number of gonads scored for each condition. ${ }^{* *} \mathrm{p}=0.0018$ and ${ }^{* * *} \mathrm{p}<0.0001$, two-sided Student $t$-test.

(H) The abundance of HA-tagged wild-type and mutant CHK-2 proteins compared by Western blot: HA::CHK-2 WT, S116A, S116D, T120A, and T120D were all measured in heterozygotes. HA::CHK-2 WT and S116A were readily detected, while other mutant proteins are near or below the limit of detection. Because the chk-2 mutations result in very few viable progeny and cannot be readily balanced, the number of worms used per lane was limited. Tubulin was quantified as a loading control. 
bioRxiv preprint doi: https://doi.org/10.1101/2021.06.20.449183; this version posted June 21, 2021. The copyright holder for this preprint (which was not certified by peer review) is the author/funder. All rights reserved. No reuse allowed without permission.

See also Figure S4. 
EioRxiv preprint doi: https://doi.org/10.1101/2021.06.20.449183; this version posted June 21, 2021. The copyright holder for this preprint

- 19. 3 (which was not certified by peer review) is the author/funder. All rights reserved. No reuse allowed without permission.
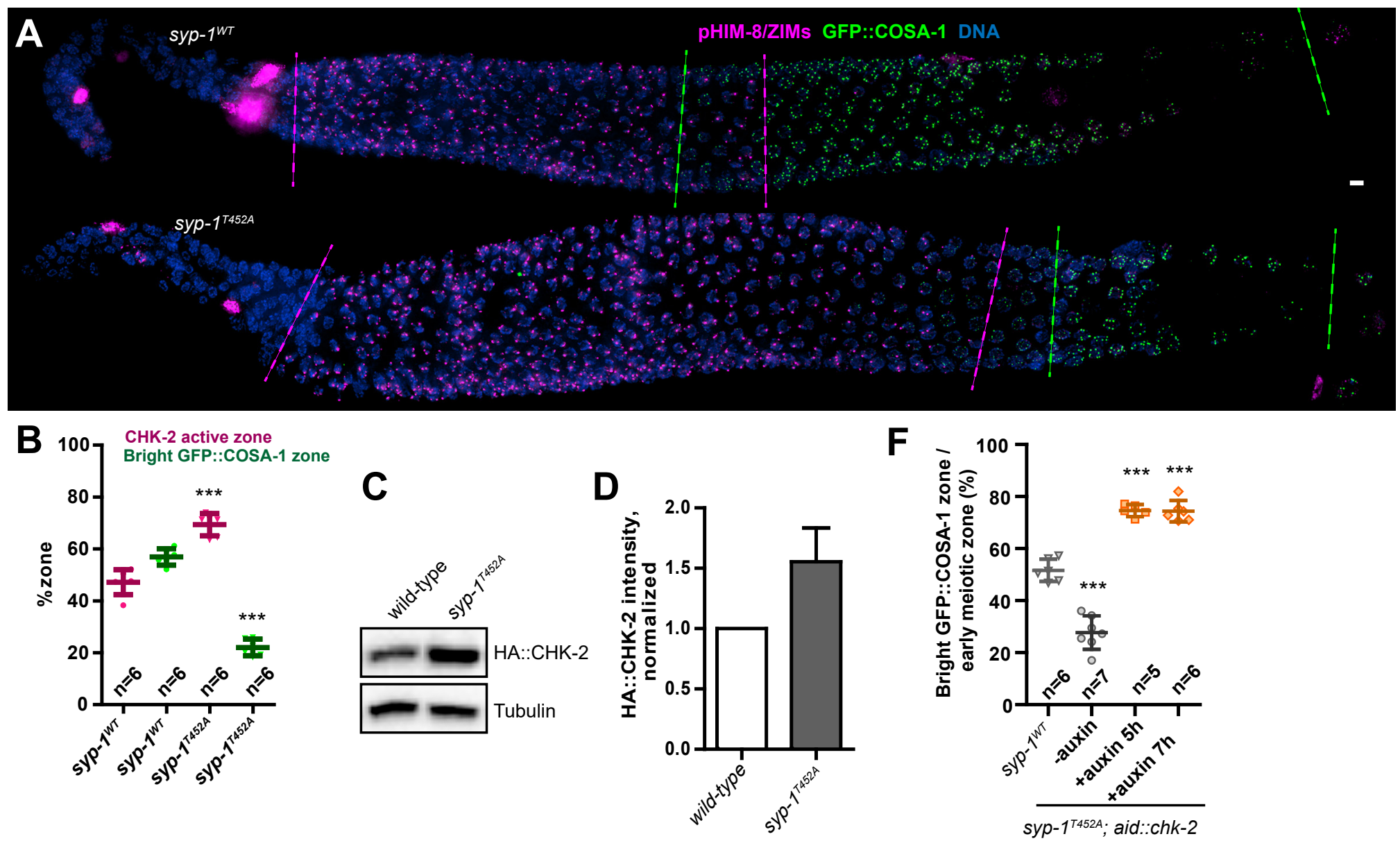

E - auxin

syp-1 ${ }^{\text {T452A }}$; aid:::chk-2

GFP::COSA-1 DNA

tauxin $5 \mathrm{~h}$

$+\operatorname{auxin} 7 \mathrm{~h}$ 


\section{Figure 3. CHK-2 inactivation requires recruitment of Polo-like kinases to the SC}

(A) Representative hermaphrodite gonads stained for pHIM-8/ZIMs (magenta), GFP::COSA1 (green) and DNA (blue), showing extension of CHK-2 active zone and delayed CO designation in $s y p-1^{T 452 A}$ mutants, which lack an important Polo-like kinase recruitment motif on the SC (Sato-Carlton et al., 2017). Dashed magenta lines indicate the CHK-2 active zone, while green lines indicate the designated CO zone. Scale bars, $5 \mu \mathrm{m}$.

(B) Quantification of the extension of CHK-2 active zone and the delay in CO designation in worms as described in (A). $\mathrm{n}=$ number of gonads scored for each condition. ${ }^{* * *} \mathrm{p}<0.0001$, twosided Student $t$-test.

(C) Expression level of CHK-2 in wild-type and $s y p-1^{T 452 A}$ worms. Blots were done with antiHA and anti-tubulin antibodies, respectively. Tubulin was blotted as a loading control.

(D) CHK-2 abundance was quantified by Western blotting, normalized against tubulin controls. The graph shows the mean ${ }_{ \pm} \mathrm{SD}$ protein levels from three independent experiments.

(E) Images of representative hermaphrodite gonads stained for GFP::COSA-1 (yellow) and DNA (blue), showing that depletion of CHK-2 leads to earlier CO designation in syp-1 $1^{T 452 A}$ mutants. Worms were treated with or without $1 \mathrm{mM}$ auxin for 5 or $7 \mathrm{~h}$. Dashed green lines indicate the designated CO zone. Scale bars, $5 \mu \mathrm{m}$.

(F) Quantification of designed CO zone in worms maintained and treated as in (E). Wild type worms $\left(\right.$ syp-1 $\left.1^{W T}\right)$ were used as control. $\mathrm{n}=$ number of gonads scored for each condition. ${ }^{* * *} \mathrm{p}<0.0001$, two-sided Student $t$-test.

See also Figures S2, S3 and S4. 
bioRxiv preprint doi: https://doi.org/10.1101/2021.06.20.449183; this version posted June 21, 2021. The copyright holder for this preprint

Fig. S2 (which was not certified by peer review) is the author/funder. All rights reserved. No reuse allowed without permission.

A

plk-1::aid::HA; plk-2::aid::HA

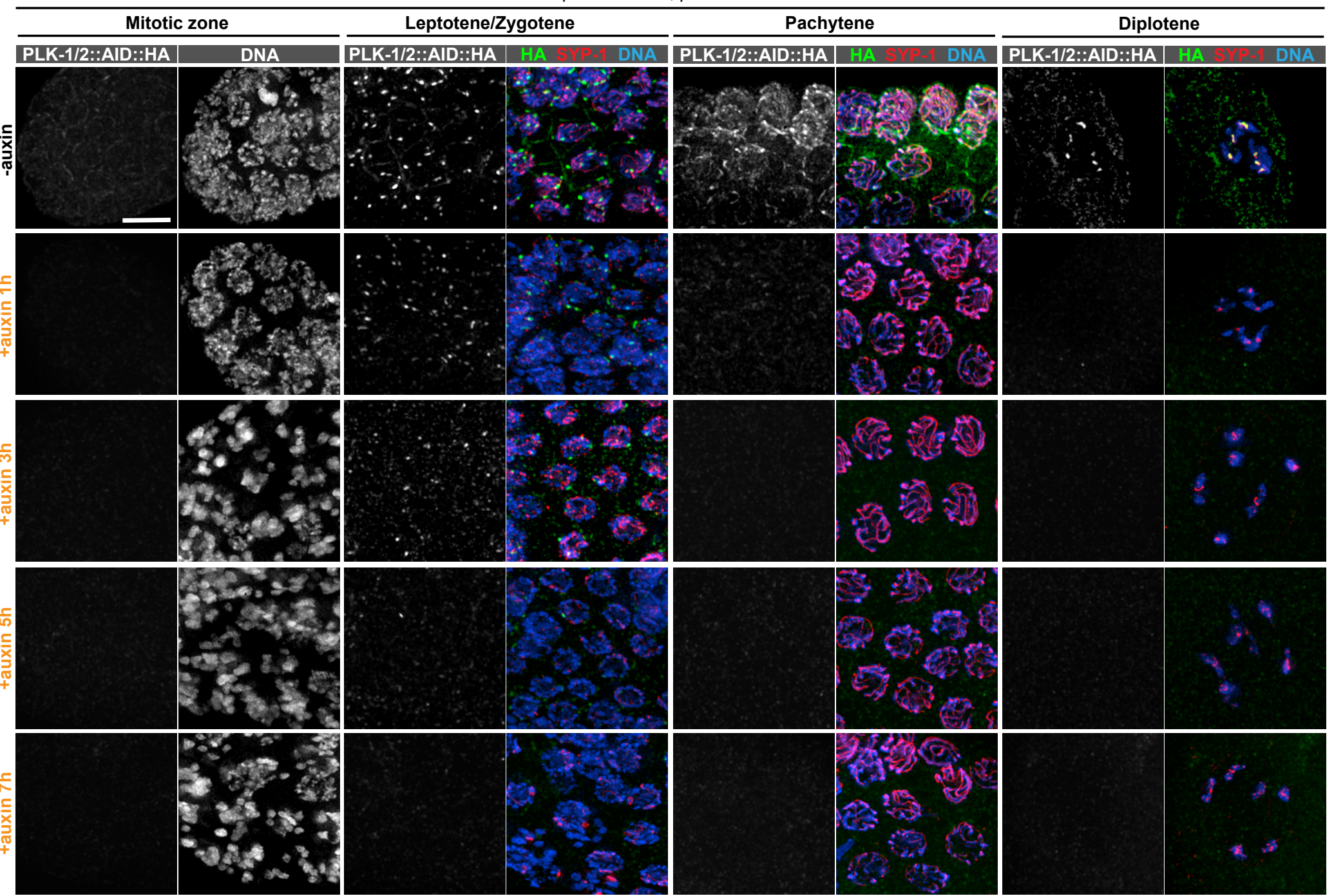

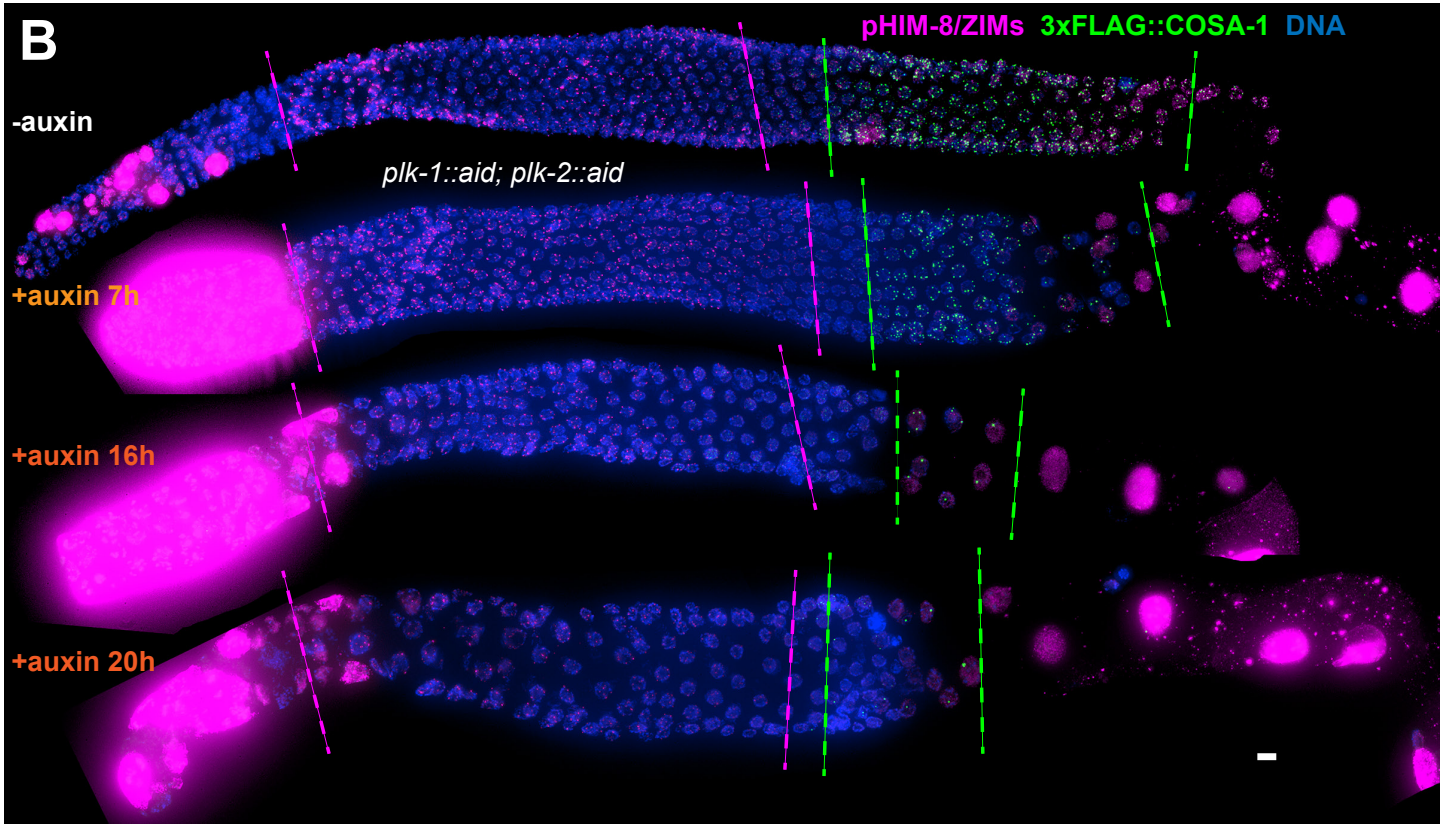

C

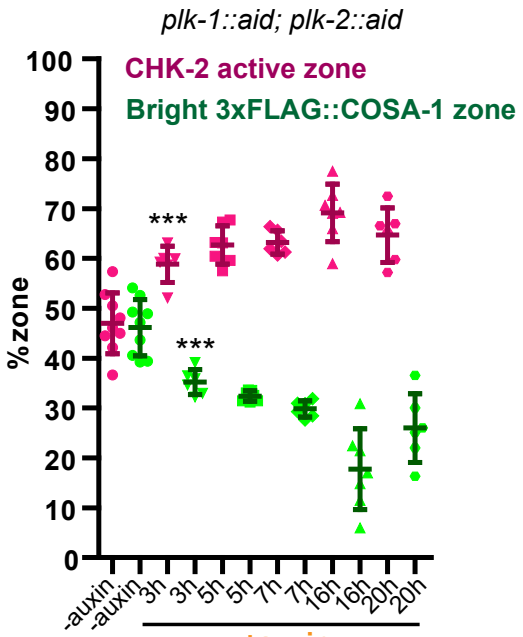


Figure S2. PLK-1 is not required to override the CO assurance checkpoint in the absence of PLK-2, Related to Figure 3.

(A) Images of representative nuclei at different stages showing efficient co-depletion of PLK1 and PLK-2 in the germline. One hour of auxin treatment was sufficient to eliminate detectable PLK-1/PLK2 in the germline except at Pairing Centers in early meiotic nuclei, where full depletion required $5 \mathrm{~h}$. Scale bars, $5 \mu \mathrm{m}$.

(B) Images of representative hermaphrodite gonads stained for $\mathrm{pHIM-8/ZIMs} \mathrm{(magenta),}$ 3xFLAG-COSA-1 (green) and DNA (blue), showing inactivation of CHK-2 and CO designation in the absence of PLK-1 and PLK-2. Magenta dashed lines indicate CHK-2 active zone, while green lines indicate bight COSA-1 zone. 3xFLAG::COSA-1 foci were greatly diminished (in most nuclei, only 1 bright 3xFLAG::COSA-1 focus can be detected) when PLK-1 and PLK-2 were co-depleted for longer than 16 hours. This likely reflects pairing and synapsis defects. However, crossover designation activity was still observed when both PLK1 and PLK-2 were depleted. Scale bars, $5 \mu \mathrm{m}$.

(C) Graphs showing extension of CHK-2 active zone and delay in $\mathrm{CO}$ designation in worms co-depleted for PLK-1 and PLK-2. The designated CO zones and CHK-2-active zones were measured as described in Figure $\mathrm{S} 1 \mathrm{~F} . \mathrm{n}=9,6,7,6,7$ and 6 gonads respectively. ${ }^{* * *} \mathrm{p}=0.0007$ and 0.0009 , respectively, two-sided Student $t$-test. 


\section{Fig. S3}

(which was not certified by peer review) is the author/funder. All rights reserved. No reuse allowed without permission.
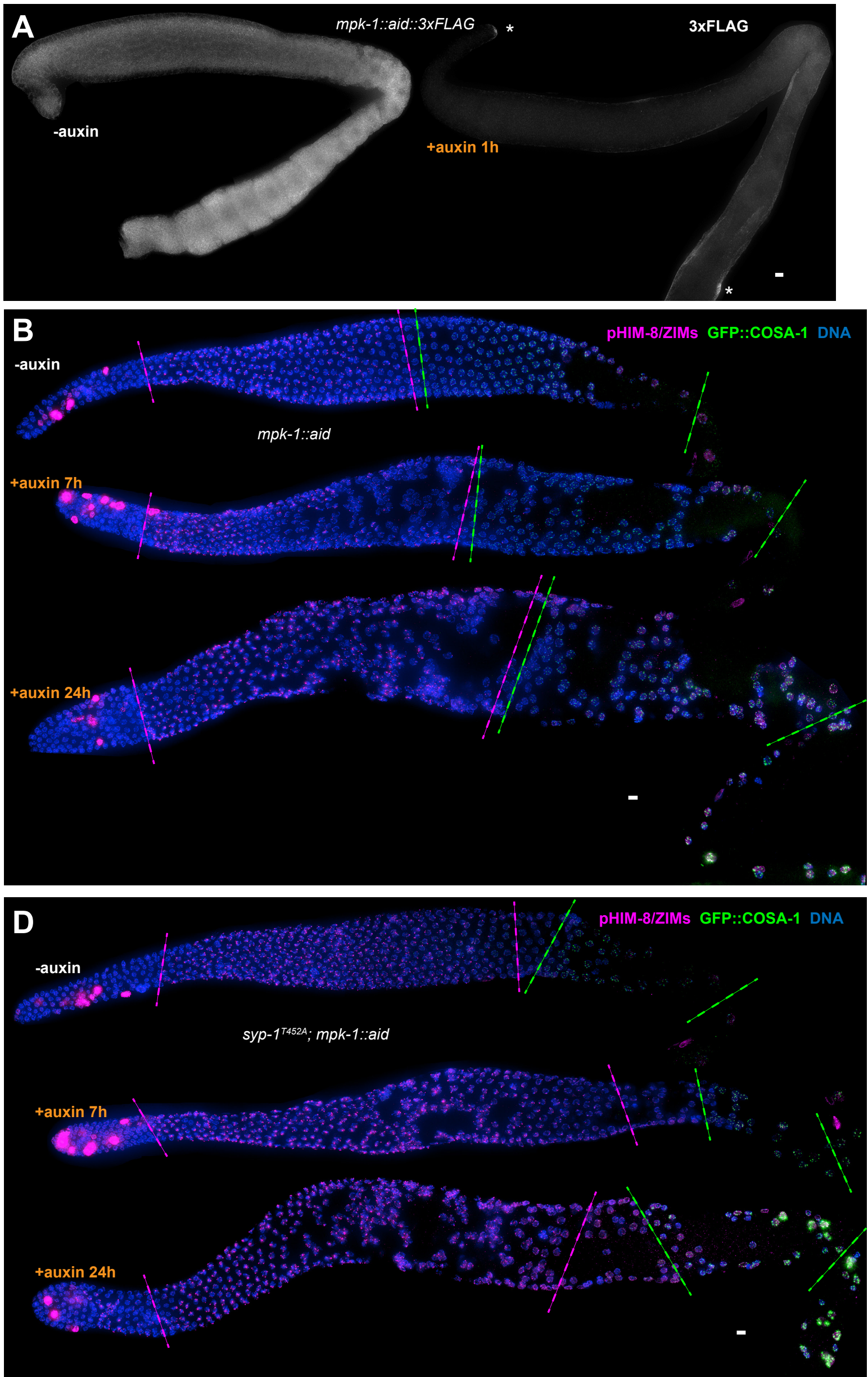

E

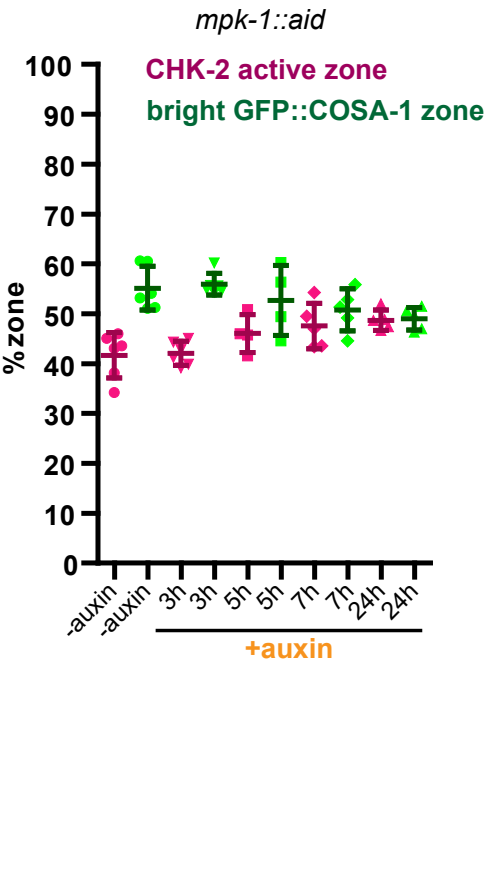

syp-1 ${ }^{\text {T452A }} ;$ mpk-1::aid

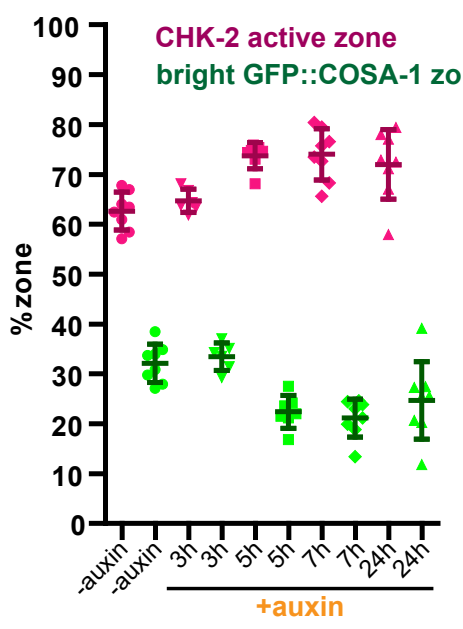


Figure S3. MPK-1 does not silence the crossover assurance checkpoint, Related to Figure 3.

(A) Representative hermaphrodite gonads showing efficient, germ-cell-specific depletion of MPK-1. Asterisks indicate the distal tip and seam cells, where TIR1 is not expressed in this strain, and MPK-1 was consequently not degraded. Scale bars, $5 \mu \mathrm{m}$.

(B) Representative hermaphrodite gonads stained for pHIM-8/ZIMs (magenta), GFP::COSA1 (green) and DNA (blue), showing inactivation of CHK-2 and CO designation in the absence of MPK-1. Magenta dashed lines indicate CHK-2 active zone, while green lines indicate bight COSA-1 zone. Scale bars, $5 \mu \mathrm{m}$.

(C) Graphs showing CHK-2 active zone and designated CO zone in worms depleted for MPK-1 for various length of time. In this case, the designated CO and CHK-2-active zones were measured as a fraction of the region from meiotic onset to the turn of the gonad instead of the end of pachytene, because mpk-1 depletion perturbs pachytene exit and formation of a single line of oocytes. $\mathrm{n}=6,6,4,5$ and 5 gonads respectively.

(D) Images of representative hermaphrodite gonads stained for pHIM-8/ZIMs (magenta), GFP::COSA-1 (green) and DNA (blue), showing inactivation of CHK-2 and CO designation in the syp-1 ${ }^{T 452 A}$ worms depleted for MPK-1. Scale bars, $5 \mu \mathrm{m}$.

(E) Graphs showing CHK-2 active zone and designated CO zone in the syp-1 ${ }^{T 452 A}$ worms depleted for MPK-1 for various lengths of time. 'Designated CO zone' and 'CHK-2 active zone' were measured and presented as described in $(\mathrm{C}) . \mathrm{n}=8,6,7,8$ and 8 gonads respectively. 
Fig. S4 (which was not certified by peer review) is the author/funder. All rights reserved. No reuse allowed without permission.

A

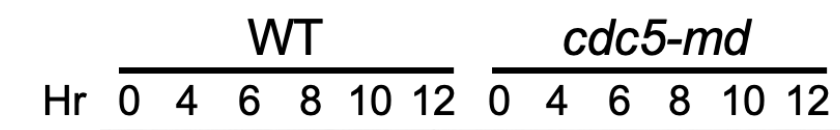

Cdc5

Zip1

Red1

Mek1

p-Hed1

Hed1

Ndt80

Arp7 $=0=0=0=0=0$
B

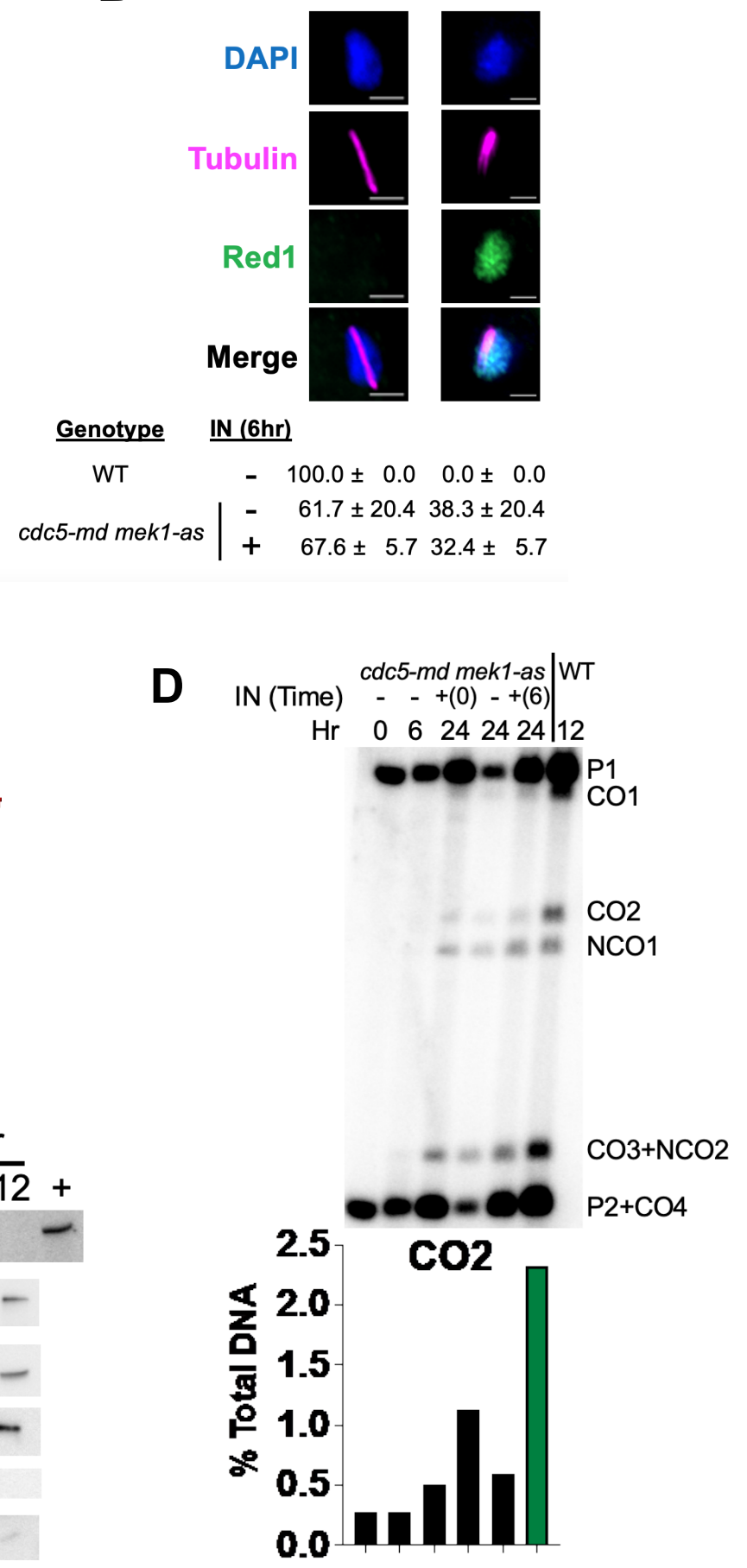

E mek1 $\Delta$

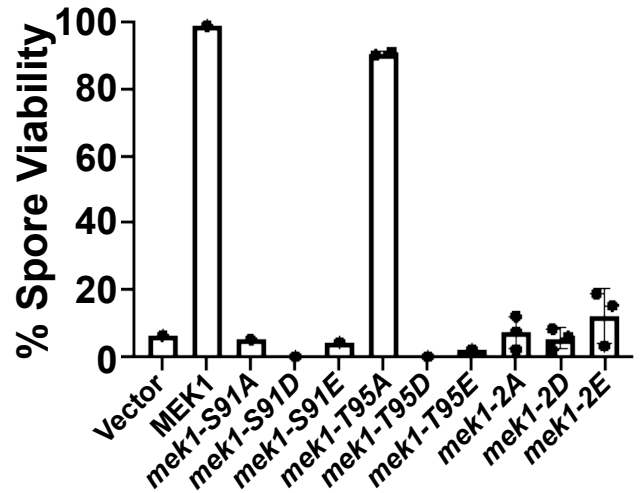




\section{Figure S4. Examination of the interplay between of Mek1 and CDC5, Related to Figures 2 and 3.}

(A) Upper panel: WT (NH716) and cdc5-md (NH2627) diploids were transferred to sporulation (Spo) medium at 0 hours and samples taken at the indicated timepoints for protein analysis. The $c d c 5$-md (meiotic depletion) allele consists of CDC5 fused to the CLB2 promoter that is only expressed in vegetative cells. Hed1 is a meiosis-specific protein that is a substrate of Mek1 and its phosphorylation (p-Hed1) is an indirect indicator of Mek1 activity that is detected by the phophospecific antibody anti-Hed1 p-T40. Arp7 is a loading control. Lower panel: Quantification of Red1 and Zip1 protein levels. Protein quantity was normalized to the total protein loaded in each lane, measured on a stain-free blot.

(B) Whole cell immunofluorescence of WT (NH2598::pSK693::pSK694) and cdc5-md mek1as (NH2625::pJR2²) diploids during meiosis. Micrographs show representative images of cells with a metaphase-like spindle either lacking Red1 (Red1-) or with nuclear Red1 (Red1 ${ }^{+}$). Scale bars are $2 \mathrm{~mm}$. The average percentage of metaphase cells that are either Red $1^{+}$or Red1- is shown with the range from two biological replicates. At least 25 metaphase cells were scored for each strain and condition.

(C) Upper panel: Immunoblots of protein extracts from a meiotic timecourse using $c d c 5$-md mek1-as (NH2625::pJR22). “+” indicates positive control for Cdc5 detection (WT cells after 6 hrs in Spo medium). At $0 \mathrm{hr}$, the $c d c 5$-md mek1-as sporulating culture was split into two $1 / 4$ cultures and one $1 / 2$ culture; either $1 \mu \mathrm{M}$ of the Mek1-as inhibitor (IN) 1 -NA-PP1, or an equivalent volume of DMSO, was added to the $1 / 4$ sporulating cultures. Nothing was added to the $1 / 2$ culture at 0 hrs. At 6 hrs, the $1 / 2$ culture was divided into two equal cultures and either $1 \mu \mathrm{M} 1-\mathrm{NA}-\mathrm{PP} 1$ or equivalent volume of DMSO was added to each. Lower panel:

Quantification of Red1 and Zip1 protein levels. The average value of two experiments is plotted, error bars show range. Protein quantity was normalized to the total protein loaded in each lane, measured on a stain-free blot.

(D) Upper panel: Physical analysis of crossovers and noncrossovers at the HIS4/LEU2 hotspot. This hotspot is flanked by XhoI sites at different positions on the two homologs with an NgoMIV restriction site located near the double strand site. Gene conversion of the NgoMIV site results in a unique noncrossover Xhol fragment (NCO1), while crossing over results in a band of unique size (CO2). DNA was isolated from the indicated timepoints from the timecourse in (D), digested with XhoI and NgoMIV and probed as described in “METHOD DETAILS". A DNA sample from wild-type meiotic cells (NH2297::p382²) at 12 hrs was used as a positive control for CO2/NCO1 detection. Lower panel: quantification of CO2 normalized to the total DNA.

(E) Spore viability of the mek1 1 diploid, YTS1, transformed with one copy of the URA3 $M E K 1$ integrating plasmid, pLP37 or its mutant derivatives. "Vector" indicates mek1 diploid transformed with the empty integrating plasmid pRS306. Each dot represents 
bioRxiv preprint doi: https://doi.org/10.1101/2021.06.20.449183; this version posted June 21, 2021. The copyright holder for this preprint (which was not certified by peer review) is the author/funder. All rights reserved. No reuse allowed without permission.

dissection data for an individual single colony. At least 25 tetrads were dissected for each mutant. 


\section{MATERIALS and METHODS}

\section{Worm strains}

All C. elegans strains were maintained on standard nematode growth medium (NGM) plates seeded with $\mathrm{OP} 50$ bacteria at $20^{\circ} \mathrm{C}$. All epitope- and degron-tagged alleles analyzed in this study were fully functional, as indicating by their ability to support normal meiosis and development (Table S1). Unless otherwise indicated, new alleles used in this study were generated by CRISPR/Cas9-mediated genome editing following a modified protocol as previously described (Arribere et al., 2014; Paix et al., 2015; Zhang et al., 2018).

See Table S2 for a list of new alleles generated in this study. Unless otherwise indicated, young adults (20-24 h post-L4) were used for both immunofluorescence and Western blot assays.

\section{Worm viability and fertility}

To quantify brood sizes, male self-progeny, and embryonic viability, L4 hermaphrodites were picked onto individual seeded plates and transferred to new plates daily over 4 days. Eggs were counted daily. Viable progeny and males were scored when they reached the L4 or adult stages.

\section{Auxin-mediated protein depletion in worms}

Auxin-mediated protein depletion was performed as previously described (Zhang et al., 2015, 2018). Briefly, worms were transferred to bacteria-seeded plates containing $1 \mathrm{mM}$ indole-3acetic acid (IAA, auxin) and incubated for the indicated time periods before analysis. 


\section{Yeast strain and plasmid construction}

All yeast strain transformations were done using lithium acetate. Plasmids carrying potential mek1 phosphosite alleles were digested with StuI to target integration at ura3 in YTS1 diploid cells. Integration of mek1 plasmids was confirmed by colony PCR.

For construction of NH2627 (cdc5-md), a kanMX6-pCLB2::CDC5 DNA fragment was PCR amplified from pMJ787 and transformed into both haploid parents to delete $50 \mathrm{bp}$ directly upstream of the $C D C 5$ start codon. This integration put the CLB2 promoter directly upstream of $C D C 5$. Correct integration of $k a n M X 6-p C L B 2:: C D C 5$ was confirmed by colony PCR in each haploid before mating.

For construction of NH2625::pJR22 (cdc5-md mek1-as), pJR2 was digested with RsrII to target integration downstream of mek14::natMX4 in both haploid parents. Proper integration of mek1-Q241G (mek1-as) on pJR2 was confirmed by colony PCR in each haploid before mating.

The candidate mek1 nonphosphorylatable and phosphomimetic integrating plasmids were generated by PCR-based site directed mutagenesis on pLP37 (de los Santos and Hollingsworth, 1999). The entire $M E K 1$ gene was sequenced to confirm mutations. Plasmids and primers used for site directed mutagenesis are shown in the Key Resources Table and Table S4.

\section{Yeast meiotic time course analysis}

Yeast media and sporulation protocol were as described in (Lo and Hollingsworth, 2011).

Mek1-as was inhibited using a final concentration of $1 \mu \mathrm{M}$ 1-NA-PP1[1-(1,1- 
Dimethylethyl)-3-(1-naphthalenyl)-1H-pyrazolo[3,4-d]pyrimidin-4-amine] (Tocris

Bioscience \#3063). The inhibitor was dissolved in dimethylsulfoxide (DMSO), and an equal volume of DMSO lacking inhibitor was added to control cultures. For protein analysis, $5 \mathrm{ml}$ cells were pelleted in $15 \mathrm{ml}$ conical tubes, supernatants discarded and the cell pellets frozen at $-80^{\circ} \mathrm{C}$. For DNA samples, $10 \mathrm{ml}$ cells were fixed with $10 \mathrm{ml}$ ethanol and $1 \mathrm{ml} 0.5 \mathrm{M}$ EDTA and stored at $-20^{\circ} \mathrm{C}$. For whole-cell immunofluorescence, $3 \times 10^{7}$ cells were fixed in $3.7 \%$ formaldehyde overnight ( $\sim 14-18$ hrs) at $4^{\circ} \mathrm{C}$. Fixed cells were then washed $1 \mathrm{X}$ in PBS and stored at $4^{\circ} \mathrm{C}$.

\section{In vitro phosphorylation assay}

Recombinant wild-type and kinase-dead CHK-2 were expressed and purified as described previously (Kim et al., 2015). For PLK-2, the full-length open reading frame (ORF) was amplified from a $C$. elegans cDNA library and cloned into pFastBac1 (Life Technologies) with a GST tag at its N-terminus. GST-PLK-2 was expressed in insect Sf9 cells using the standard Bac-to-Bac system (Life Technologies) and then purified using glutathione Sepharose (GE Life Sciences).

In vitro kinase assays were performed in a buffer comprised of $20 \mathrm{mM}$ HEPES pH 7.5, $25 \mathrm{mM}$ $\mathrm{NaCl}, 1 \mathrm{mM} \mathrm{MgCl}$, and $1 \mathrm{mM}$ DTT, supplemented with $0.5 \mathrm{mM} \mathrm{Mg}$-ATP. $2 \mu \mathrm{M}$ of GST-

CHK-2 KD were incubated with or without $0.2 \mu \mathrm{M}$ of GST-PLK-2 at room temperature for 1 hour. Kinase reactions were terminated by addition of SDS sample buffer and proteins were electrophoresed using gradient polyacrylamide gels (Genscript). The CHK-2 bands were excised, subjected to trypsin digestion, and phosphorylation sites were identified using Mass 
Spectrometry analyses (UC Davis).

\section{Microscopy}

Immunofluorescence experiments for C. elegans were performed as previously described (Zhang et al., 2018). Images shown in the Supplementary Figure S3A were obtained from worms dissected and fixed in the absence of Tween-20 to retain soluble proteins. Primary antibodies were obtained from commercial sources or have been previously described, and were diluted as follows: Rabbit anti-RAD-51 (1:5,000, Novus Biologicals, \#29480002), Rabbit anti-pHIM-8/ZIMs [1:500, (Kim et al., 2015), Goat anti-SYP-1 [1:300, (Harper et al., 2011), Chicken anti-HTP-3 [1:500, (MacQueen et al., 2005), Mouse anti-HA (1:400, Thermo Fisher, \#26183), Mouse anti-GFP (1:500, Millipore Sigma, \#11814460001). Secondary antibodies labeled with Alexa 488, Cy3 or Cy5 were purchased from Jackson ImmunoResearch (WestGrove, PA) and used at 1:500. All images were acquired as z-stacks through 8-12 $\mu \mathrm{m}$ depth at z-intervals of $0.2 \mu \mathrm{m}$ using a DeltaVision Elite microscope (GE) with a 100x, 1.4 N.A. or $60 x, 1.42$ N.A. oil-immersion objective. Iterative 3D deconvolution, image projection and colorization were carried out using the softWoRx package and Adobe Photoshop CC 2017.

Whole yeast cell immunofluorescence: For spheroplasting, $1 \times 10^{7}$ cells were incubated in 75 $\mu \mathrm{l}$ ZK buffer (25 mM Tris-Cl pH7.5, 0.8 M KCl) + 0.04 M Dithiothreitol (DTT) for 2 min at room temperature. The cells were pelleted and the supernatant was removed. The cell pellets were resuspended in $75 \mu \mathrm{l} \mathrm{ZK}$ buffer $+0.1 \mathrm{mg} / \mathrm{mL}$ zymolyase 100T (US Biological Z1004) and incubated on ice for $10 \mathrm{~min}$. Spheroplasted cells were centrifuged at low speed (900 x g) and 
washed $1 \mathrm{X}$ in $500 \mu \mathrm{l}$ ice cold sorbitol/MES buffer (1M Sorbitol, 0.1M MES pH6.5, $1 \mathrm{mM}$

EDTA, $0.5 \mathrm{mM} \mathrm{MgCl} 2$ ). After washing, cells were resuspended in $150 \mu \mathrm{l}$ sorbitol/MES $+0.1 \%$

Triton X-100 and incubated $5 \mathrm{~min}$ at room temperature to permeabilize the cell membrane.

The sorbitol/MES buffer wash was repeated.

Permeabilized cells were resuspended in $40 \mu \mathrm{l}$ sorbitol/MES buffer. $30 \mu \mathrm{l}$ of resuspended cells were transferred to wells of a printed microscope slide (Carlson Scientific cat\# 101205). After allowing cells to settle onto the slide for $15 \mathrm{~min}$, the remaining liquid was aspirated away. The slides were placed into a Coplin jar containing methanol at $-20^{\circ} \mathrm{C}$ for $6 \mathrm{~min}$ and then transferred to a Coplin jar with acetone at $-20^{\circ} \mathrm{C}$ for 30 seconds. Afterwards, slides were air dried until all the residual acetone evaporated.

$30 \mu \mathrm{l}$ of 1\% Bovine serum albumin (BSA) in TBS buffer (140 mM NaCl, $2.7 \mathrm{mM} \mathrm{KCl,} 25 \mathrm{mM}$ Tris pH8.0) was added to each well and incubated for $30 \mathrm{~min}$ at room temperature in a slide box with moist paper towels. After incubation, slides were washed in TBS buffer for 30 sec.

Excess TBS was removed by blotting an edge on a paper towel. The rat anti- $\alpha$-tubulin polyclonal antibody (BioRad cat\# MCA78G) and rabbit anti-Red1 polyclonal antibody (Wan et al., 2004) were diluted 1:200 and 1:300, respectively, in 1\% BSA. $80 \mu$ l of primary antibody dilution was added to the entire slide, then a $25 \times 50 \mathrm{~mm}$ coverslip was placed onto the slide. Primary antibodies were incubated overnight $(\sim 14-18 \mathrm{hrs})$ at $4^{\circ} \mathrm{C}$ in slide box with moist paper towels. The next day, coverslips were removed in TBS and slides washed $2 \mathrm{X}$ in TBS for 10 min. The anti-rabbit Alexa 488 antibody (Fisher Cat\# A11008) and anti-rat Alexa 546 
antibody (Fisher Cat\# A11081) were both diluted 1:1000 in 1\% BSA. $80 \mu$ l of secondary antibody dilution was added to each slide and covered with a coverslip. Secondary antibodies were incubated for $2 \mathrm{hr}$ at $4^{\circ} \mathrm{C}$ in slide box with moist paper towels. After secondary antibody incubation, coverslips were removed in TBS and slides were washed $2 \mathrm{X}$ in TBS for 10 min. Slides were completely air dried and $3 \mu \mathrm{L}$ DAPI plus mounting medium (Vectashield H-1200) was added to each well. A coverslip was added to the slide and sealed with nail polish. Microscopy images were taken using a Zeiss Axio Imager.Z2 microscope with a Zeiss Plan-Apochromat 63x objective.

\section{Western blotting}

Adult worms were picked into S-basal buffer and lysed by addition of SDS sample buffer, followed by boiling for 15 min with occasional vortexing. Whole worm lysates were then separated on $4-12 \%$ polyacrylamide gradient gels (GenScript), transferred to membranes, and blotted with mouse anti-HA (1:1,000, Thermo Fisher, \#26183), or mouse anti- $\alpha$-tubulin (1:5,000, Millipore Sigma, \#05-829). HRP-conjugated anti-mouse secondary antibodies (Jackson Immunoresearch \#115-035-068) and SuperSignal West Femto Maximum Sensitivity Substrate (Thermo Fisher, \#34095) were used for detection.

Yeast protein extracts were made using a trichloroacetic acid method as previously described (Falk et al., 2010). Extracts were separated on acrylamide gels as previously described (Prugar et al., 2017). Immunoblots in Figure S4 were blocked in 5\% dry milk for $1 \mathrm{hr}$ at room temperature or overnight at $4^{\circ} \mathrm{C}$ with gentle shaking. Primary antibodies were diluted into $5 \%$ dry milk and blots incubated for 2 hrs at room temperature or 16-20 hrs overnight at 4․ $\mathrm{C}$. 
Primary antibodies were diluted as follows: goat anti-Cdc5 (1:2,000, Santa Cruz, \#sc-6733), rabbit anti-Hed1 pT40 (1:10,000, N. M. Hollingsworth), rabbit anti-Hed1 (1:50,000, Patrick Sung), rabbit anti-Red1 (1:10,000, N. M. Hollingsworth), rabbit anti-Zip1 p-S816 (1:2,000, N.

M. Hollingsworth), rabbit anti-Zip1 (1:3,000, Santa Cruz \#sc-33733), guinea pig anti-Mek1

(1:20,000, N. M. Hollingsworth), rabbit anti-Ndt80 (1:5,000, Michael Lichten), goat antiArp7 (1:50,000, Santa Cruz \#sc-8961).

Secondary antibodies conjugated to horseradish peroxidase were incubated at room temperature for $1 \mathrm{hr}$. Blots were washed 3X in TBST buffer for 5 mins after probing with primary and secondary antibodies. WesternBright ECL (VWR, \#K12045D20) was used for immunoblot development. Chemiluminescence was detected by exposing for $30 \mathrm{~s}$ to $10 \mathrm{~min}$ on BioRad ChemiDoc.

Protein bands were quantified using BioRad Image Lab software. The pixel density detected at 0 hrs was regarded as background and subtracted from measured values for meiosisspecific proteins. Protein band densities were normalized to the total protein loaded in each lane, as measured by the pixel density from BioRad stain-free blot system (BioRad cat\# 1610181).

\section{Southern blotting}

DNA was isolated using the MasterPure Yeast DNA Purification Kit (Lucigen MPY80200). DNA was digested with XhoI and NgoMIV, fractionated on a $0.6 \%$ agarose gel and probed as previously described (Oh et al., 2009). 


\section{REFERENCES}

Arribere, J.A., Bell, R.T., Fu, B.X.H., Artiles, K.L., Hartman, P.S., and Fire, A.Z. (2014). Efficient marker-free recovery of custom genetic modifications with CRISPR/Cas9 in Caenorhabditis elegans. Genetics 198, 837-846.

Baudat, F., Imai, Y., and de Massy, B. (2013). Meiotic recombination in mammals: localization and regulation. Nat Rev Genet 14, 794-806.

Broverman, S.A., and Meneely, P.M. (1994). Meiotic mutants that cause a polar decrease in recombination on the X chromosome in Caenorhabditis elegans. Genetics 136, 119-127.

Carballo, J.A., Johnson, A.L., Sedgwick, S.G., and Cha, R.S. (2008). Phosphorylation of the axial element protein Hop1 by Mec1/Tel1 ensures meiotic interhomolog recombination. Cell 132, 758-770.

Castellano-Pozo, M., Pacheco, S., Sioutas, G., Jaso-Tamame, A.L., Dore, M.H., Karimi, M.M., and Martinez-Perez, E. (2020). Surveillance of cohesin-supported chromosome structure controls meiotic progression. Nat Commun 11, 4345.

Chase, D., Serafinas, C., Ashcroft, N., Kosinski, M., Longo, D., Ferris, D.K., and Golden, A. (2000). The polo-like kinase PLK-1 is required for nuclear envelope breakdown and the completion of meiosis in Caenorhabditis elegans. Genesis 26, 26-41.

Church, D.L., Guan, K.L., and Lambie, E.J. (1995). Three genes of the MAP kinase cascade, mek-2, mpk1 sur-1 and let-60 ras, are required for meiotic cell cycle progression in Caenorhabditis elegans.

Development 121, 2525-2535.

Clyne, R.K., Katis, V.L., Jessop, L., Benjamin, K.R., Herskowitz, I., Lichten, M., and Nasmyth, K. (2003). Polo-like kinase $\mathrm{Cdc} 5$ promotes chiasmata formation and cosegregation of sister centromeres at meiosis I. Nat Cell Biol 5, 480-485.

Dernburg, A.F., Zalevsky, J., Colaiácovo, M.P., and Villeneuve, A.M. (2000). Transgene-mediated cosuppression in the C. elegans germ line. Genes Dev. 14, 1578-1583.

Falk, J.E., Chan, A.C., Hoffmann, E., and Hochwagen, A. (2010). A Mec1- and PP4-Dependent Checkpoint Couples Centromere Pairing to Meiotic Recombination. Developmental Cell 19, 599-611.

Ferrandiz, N., Barroso, C., Telecan, O., Shao, N., Kim, H.-M., Testori, S., Faull, P., Cutillas, P., Snijders, A.P., Colaiácovo, M.P., et al. (2018). Spatiotemporal regulation of Aurora B recruitment ensures release of cohesion during C. elegans oocyte meiosis. Nat Commun 9, 834.

Goodyer, W., Kaitna, S., Couteau, F., Ward, J.D., Boulton, S.J., and Zetka, M. (2008). HTP-3 Links DSB Formation with Homolog Pairing and Crossing Over during C. elegans Meiosis. Developmental Cell 14, 263-274. 
Harper, N.C., Rillo, R., Jover-Gil, S., Assaf, Z.J., Bhalla, N., and Dernburg, A.F. (2011). Pairing centers recruit a Polo-like kinase to orchestrate meiotic chromosome dynamics in C. elegans. Developmental Cell 21, 934.

Hayashi, M., Chin, G.M., and Villeneuve, A.M. (2007). C. elegans Germ Cells Switch between Distinct Modes of Double-Strand Break Repair During Meiotic Prophase Progression. PLoS Genet 3, e191.

Hodgkin, J., Horvitz, H.R., and Brenner, S. (1979). Nondisjunction Mutants of the Nematode CAENORHABDITIS ELEGANS. Genetics 91, 67-94.

Hollingsworth, N.M., and Gaglione, R. (2019). The meiotic-specific Mek1 kinase in budding yeast regulates interhomolog recombination and coordinates meiotic progression with double-strand break repair. Curr Genet 65, 631-641.

Jordan, P., Karppinen, J., and Handel, M. (2012). Polo-like kinase is required for synaptonemal complex disassembly and phosphorylation in mouse spermatocytes. Journal of Cell Science jcs.105015.

Keeney, S., Lange, J., and Mohibullah, N. (2014). Self-organization of meiotic recombination initiation: general principles and molecular pathways. Annu Rev Genet 48, 187-214.

Kim, Y., Kostow, N., and Dernburg, A.F. (2015). The Chromosome Axis Mediates Feedback Control of CHK-2 to Ensure Crossover Formation in C. elegans. Developmental Cell 35, 247-261.

Labella, S., Woglar, A., Jantsch, V., and Zetka, M. (2011). Polo kinases establish links between meiotic chromosomes and cytoskeletal forces essential for homolog pairing. Dev Cell 21, 948-958.

Lee, M.-H., Ohmachi, M., Arur, S., Nayak, S., Francis, R., Church, D., Lambie, E., and Schedl, T. (2007). Multiple Functions and Dynamic Activation of MPK-1 Extracellular Signal-Regulated Kinase Signaling in Caenorhabditis elegans Germline Development. Genetics 177, 2039-2062.

Link, J., Paouneskou, D., Velkova, M., Daryabeigi, A., Laos, T., Labella, S., Barroso, C., Pacheco Piñol, S., Montoya, A., Kramer, H., et al. (2018). Transient and Partial Nuclear Lamina Disruption Promotes Chromosome Movement in Early Meiotic Prophase. Dev Cell 45, 212-225.e7.

Lo, H.-C., and Hollingsworth, N.M. (2011). Using the Semi-synthetic Epitope System to Identify Direct Substrates of the Meiosis-Specific Budding Yeast Kinase, Mek1. In DNA Recombination: Methods and Protocols, H. Tsubouchi, ed. (Totowa, NJ: Humana Press), pp. 135-149.

MacKenzie, A.M., and Lacefield, S. (2020). CDK Regulation of Meiosis: Lessons from S. cerevisiae and S. pombe. Genes 11, 723.

MacQueen, A.J., and Villeneuve, A.M. (2001). Nuclear reorganization and homologous chromosome pairing during meiotic prophase require C. elegans chk-2. Genes Dev. 15, 1674-1687. 
MacQueen, A.J., Phillips, C.M., Bhalla, N., Weiser, P., Villeneuve, A.M., and Dernburg, A.F. (2005). Chromosome Sites Play Dual Roles to Establish Homologous Synapsis during Meiosis in C. elegans. Cell 123, 1037-1050.

Martinez-Perez, E., Schvarzstein, M., Barroso, C., Lightfoot, J., Dernburg, A.F., and Villeneuve, A.M. (2008). Crossovers trigger a remodeling of meiotic chromosome axis composition that is linked to twostep loss of sister chromatid cohesion. Genes Dev. 22, 2886-2901.

Matos, J., Blanco, M.G., Maslen, S., Skehel, J.M., and West, S.C. (2011). Regulatory Control of the Resolution of DNA Recombination Intermediates during Meiosis and Mitosis. Cell 147, 158-172.

Meneely, P.M., McGovern, O.L., Heinis, F.I., and Yanowitz, J.L. (2012). Crossover Distribution and Frequency Are Regulated by him-5 in Caenorhabditis elegans. Genetics 190, 1251-1266.

Nadarajan, S., Mohideen, F., Tzur, Y.B., Ferrandiz, N., Crawley, O., Montoya, A., Faull, P., Snijders, A.P., Cutillas, P.R., Jambhekar, A., et al. (2016). The MAP kinase pathway coordinates crossover designation with disassembly of synaptonemal complex proteins during meiosis. ELife 5, e12039.

Nadarajan, S., Lambert, T.J., Altendorfer, E., Gao, J., Blower, M.D., Waters, J.C., and Colaiácovo, M.P. (2017). Polo-like kinase-dependent phosphorylation of the synaptonemal complex protein SYP-4 regulates double-strand break formation through a negative feedback loop. ELife 6, e23437.

Nishimura, K., Fukagawa, T., Takisawa, H., Kakimoto, T., and Kanemaki, M. (2009). An auxin-based degron system for the rapid depletion of proteins in nonplant cells. Nat Methods 6, 917-922.

Niu, H., Li, X., Job, E., Park, C., Moazed, D., Gygi, S.P., and Hollingsworth, N.M. (2007). Mek1 Kinase Is Regulated To Suppress Double-Strand Break Repair between Sister Chromatids during Budding Yeast Meiosis. MCB 27, 5456-5467.

Notredame, C., Higgins, D.G., and Heringa, J. (2000). T-coffee: a novel method for fast and accurate multiple sequence alignment11Edited by J. Thornton. Journal of Molecular Biology 302, 205-217.

Oh, S.D., Jessop, L., Lao, J.P., Allers, T., Lichten, M., and Hunter, N. (2009). Stabilization and Electrophoretic Analysis of Meiotic Recombination Intermediates in Saccharomyces cerevisiae. In Meiosis: Volume 1, Molecular and Genetic Methods, S. Keeney, ed. (Totowa, NJ: Humana Press), pp. 209-234.

Oishi, I., Iwai, K., Kagohashi, Y., Fujimoto, H., Kariya, K., Kataoka, T., Sawa, H., Okano, H., Otani, H., Yamamura, H., et al. (2001). Critical role of Caenorhabditis elegans homologs of Cds1 (Chk2)-related kinases in meiotic recombination. Mol Cell Biol 21, 1329-1335.

Ortega, S., Prieto, I., Odajima, J., Martín, A., Dubus, P., Sotillo, R., Barbero, J.L., Malumbres, M., and Barbacid, M. (2003). Cyclin-dependent kinase 2 is essential for meiosis but not for mitotic cell division in mice. Nat Genet 35, 25-31. 
Page, S.L., and Hawley, R.S. (2003). Chromosome choreography: the meiotic ballet. Science 301, 785789.

Paix, A., Folkmann, A., Rasoloson, D., and Seydoux, G. (2015). High Efficiency, Homology-Directed Genome Editing in Caenorhabditis elegans Using CRISPR-Cas9 Ribonucleoprotein Complexes. Genetics 201, 47-54.

Pérez-Hidalgo, L., Moreno, S., and San-Segundo, P.A. (2003). Regulation of meiotic progression by the meiosis-specific checkpoint kinase Mek1 in fission yeast. J Cell Sci 116, 259-271.

Petronczki, M., Siomos, M.F., and Nasmyth, K. (2003). Un ménage à quatre: the molecular biology of chromosome segregation in meiosis. Cell 112, 423-440.

Phillips, C.M., and Dernburg, A.F. (2006). A Family of Zinc-Finger Proteins Is Required for ChromosomeSpecific Pairing and Synapsis during Meiosis in C. elegans. Developmental Cell 11, 817-829.

Phillips, C.M., Wong, C., Bhalla, N., Carlton, P.M., Weiser, P., Meneely, P.M., and Dernburg, A.F. (2005). $\mathrm{HIM}-8$ binds to the $\mathrm{X}$ chromosome pairing center and mediates chromosome-specific meiotic synapsis. Cell 123, 1051-1063.

Prugar, E., Burnett, C., Chen, X., and Hollingsworth, N.M. (2017). Coordination of Double Strand Break Repair and Meiotic Progression in Yeast by a Mek1-Ndt80 Negative Feedback Loop. Genetics 206, 497512.

Roelens, B., Barroso, C., Montoya, A., Cutillas, P., Zhang, W., Woglar, A., Girard, C., Martinez-Perez, E., and Villeneuve, A.M. (2019). Spatial Regulation of Polo-Like Kinase Activity During Caenorhabditis elegans Meiosis by the Nucleoplasmic HAL-2/HAL-3 Complex. Genetics 213, 79-96.

Rosu, S., Zawadzki, K.A., Stamper, E.L., Libuda, D.E., Reese, A.L., Dernburg, A.F., and Villeneuve, A.M. (2013). The C. elegans DSB-2 Protein Reveals a Regulatory Network that Controls Competence for Meiotic DSB Formation and Promotes Crossover Assurance. PLOS Genetics 9, e1003674.

Santamaria, A., Wang, B., Elowe, S., Malik, R., Zhang, F., Bauer, M., Schmidt, A., Silljé, H.H.W., Körner, R., and Nigg, E.A. (2011). The Plk1-dependent Phosphoproteome of the Early Mitotic Spindle. Mol Cell Proteomics 10.

de los Santos, T., and Hollingsworth, N.M. (1999). Red1p, a MEK1-dependent Phosphoprotein That Physically Interacts with Hop1p during Meiosis in Yeast. Journal of Biological Chemistry 274, 1783-1790.

Sato-Carlton, A., Nakamura-Tabuchi, C., Chartrand, S.K., Uchino, T., and Carlton, P.M. (2017). Phosphorylation of the synaptonemal complex protein SYP-1 promotes meiotic chromosome segregation. Journal of Cell Biology 217, 555-570.

Sato-Carlton, A., Nakamura-Tabuchi, C., Li, X., Boog, H., Lehmer, M.K., Rosenberg, S.C., Barroso, C., Martinez-Perez, E., Corbett, K.D., and Carlton, P.M. (2020). Phosphoregulation of HORMA domain 
protein HIM-3 promotes asymmetric synaptonemal complex disassembly in meiotic prophase in Caenorhabditis elegans. PLOS Genetics 16, e1008968.

Sourirajan, A., and Lichten, M. (2008). Polo-like kinase Cdc5 drives exit from pachytene during budding yeast meiosis. Genes Dev 22, 2627-2632.

Stamper, E.L., Rodenbusch, S.E., Rosu, S., Ahringer, J., Villeneuve, A.M., and Dernburg, A.F. (2013). Identification of DSB-1, a Protein Required for Initiation of Meiotic Recombination in Caenorhabditis elegans, Illuminates a Crossover Assurance Checkpoint. PLOS Genetics 9, e1003679.

Vugt, M.A.T.M. van, Gardino, A.K., Linding, R., Ostheimer, G.J., Reinhardt, H.C., Ong, S.-E., Tan, C.S., Miao, H., Keezer, S.M., Li, J., et al. (2010). A Mitotic Phosphorylation Feedback Network Connects Cdk1, Plk1, 53BP1, and Chk2 to Inactivate the G2/M DNA Damage Checkpoint. PLoS Biology 8.

Wan, L., de los Santos, T., Zhang, C., Shokat, K., and Hollingsworth, N.M. (2004). Mek1 Kinase Activity Functions Downstream of RED1 in the Regulation of Meiotic Double Strand Break Repair in Budding Yeast. MBoC 15, 11-23.

Wijnker, E., Harashima, H., Müller, K., Parra-Nuñez, P., de Snoo, C.B., van de Belt, J., Dissmeyer, N., Bayer, M., Pradillo, M., and Schnittger, A. (2019). The Cdk1/Cdk2 homolog CDKA;1 controls the recombination landscape in Arabidopsis. Proc Natl Acad Sci U S A 116, 12534-12539.

Woglar, A., and Villeneuve, A.M. (2018). Dynamic Architecture of DNA Repair Complexes and the Synaptonemal Complex at Sites of Meiotic Recombination. Cell 173, 1678-1691.e16.

Woglar, A., Daryabeigi, A., Adamo, A., Habacher, C., Machacek, T., Volpe, A.L., and Jantsch, V. (2013). Matefin/SUN-1 Phosphorylation Is Part of a Surveillance Mechanism to Coordinate Chromosome Synapsis and Recombination with Meiotic Progression and Chromosome Movement. PLOS Genetics 9, e1003335.

Xu, L., Ajimura, M., Padmore, R., Klein, C., and Kleckner, N. (1995). NDT80, a meiosis-specific gene required for exit from pachytene in Saccharomyces cerevisiae. Mol Cell Biol 15, 6572-6581.

Yokoo, R., Zawadzki, K.A., Nabeshima, K., Drake, M., Arur, S., and Villeneuve, A.M. (2012). COSA-1 Reveals Separable Licensing and Reinforcement Steps and Efficient Homeostasis Governing Meiotic Crossovers. Cell 149, 75-87.

Yu, Z., Kim, Y., and Dernburg, A.F. (2016). Meiotic recombination and the crossover assurance checkpoint in Caenorhabditis elegans. Seminars in Cell \& Developmental Biology 54, 106-116.

Zetka, M.C., Kawasaki, I., Strome, S., and Müller, F. (1999). Synapsis and chiasma formation in Caenorhabditis elegans require HIM-3, a meiotic chromosome core component that functions in chromosome segregation. Genes Dev. 13, 2258-2270.

Zhang, L., Ward, J.D., Cheng, Z., and Dernburg, A.F. (2015). The auxin-inducible degradation (AID) system enables versatile conditional protein depletion in C. elegans. Development 142, 4374-4384. 
Zhang, L., Köhler, S., Rillo-Bohn, R., and Dernburg, A.F. (2018). A compartmentalized signaling network mediates crossover control in meiosis. ELife 7, e30789.

Zhang, W., Miley, N., Zastrow, M.S., MacQueen, A.J., Sato, A., Nabeshima, K., Martinez-Perez, E., Mlynarczyk-Evans, S., Carlton, P.M., and Villeneuve, A.M. (2012). HAL-2 Promotes Homologous Pairing during Caenorhabditis elegans Meiosis by Antagonizing Inhibitory Effects of Synaptonemal Complex Precursors. PLOS Genetics 8, e1002880. 


\section{Supplemental Table S1}

Viability and fertility of representative transgenic worm strains

\begin{tabular}{|c|c|c|c|}
\hline Strains & $\begin{array}{l}\text { Eggs laid }( \pm \mathrm{SD}) \\
(\mathrm{n}=6 \text { broods })\end{array}$ & $\begin{array}{l}\text { Egg viability } \\
( \pm \mathrm{SD})(\%)\end{array}$ & $\begin{array}{l}\text { Male progeny } \\
( \pm \mathrm{SD})(\%)\end{array}$ \\
\hline WT & $261( \pm 17)$ & $106.64( \pm 5.07)$ & $0.13( \pm 0.30)$ \\
\hline $\begin{array}{l}\text { meIs8[pie-1p::GFP::cosa-1, unc-119(+)] II; ieSi38[sun- } \\
\text { 1p::tir1:::mRuby::sun-1 3' UTR, Cbr-unc-119(+)] } \\
\text { IV;chk-2(ie121[HA:::aid::chk-2]) V }\end{array}$ & $295( \pm 26.51)$ & $105.63( \pm 3.09)$ & $0.27( \pm 0.25)$ \\
\hline $\begin{array}{l}\text { meIs8[pie-1p::GFP::cosa-1, unc-119(+)] II; ieSi38[sun- } \\
\text { 1p::tir1:::mRuby::sun-1 3' UTR, Cbr-unc-119(+)] } \\
\text { IV;chk-2(ie127[HA:::chk-2]) V }\end{array}$ & $202.33( \pm 24.12)$ & $103.68( \pm 3.64)$ & $0.15( \pm 0.38)$ \\
\hline $\begin{array}{l}\text { plk-2(ie5O[plk-2::mRuby]; meIs8[pie-1p::GFP::cosa-1, } \\
\text { unc-119(+)] II; mpk-1(ie54[aid::3xFLAG::mpk-1]) III; } \\
\text { ieSi38[sun-1p::tir1::mRuby::sun-1 3' UTR, Cbr-unc- } \\
119(+)] \text { IV }\end{array}$ & $274.6( \pm 24.09)$ & $104.07( \pm 3.11)$ & $0.15( \pm 0.20)$ \\
\hline $\begin{array}{l}\text { ieSi64[gld-1p::tir1::mRuby::sun-1 3' UTR, Cbr-unc- } \\
119(+)] \text { II }\end{array}$ & $269( \pm 42.53)$ & $104.41( \pm 1.88)$ & $0.07( \pm 0.18)$ \\
\hline $\begin{array}{l}\text { plk-2(ie126[plk-2::aid::HA]) I; ieSi64[gld- } \\
\text { 1p::tir1::mRuby::sun-1 3' UTR, Cbr-unc-119(+)] II; } \\
\text { cosa-1(ie124[3xFLAG::cosa-1], plk-1(ie125[plk- } \\
\text { 1::aid::HA]) III }\end{array}$ & $300.83( \pm 40.66)$ & $101.02( \pm 1.61)$ & $0.00( \pm 0.00)$ \\
\hline
\end{tabular}

Note: viability $>100 \%$ is a consequence of failing to count some embryos. 
bioRxiv preprint doi: https://doi.org/10.1101/2021.06.20.449183; this version posted June 21, 2021. The copyright holder for this preprint (which was not certified by peer review) is the author/funder. All rights reserved. No reuse allowed without permission.

\section{Supplemental Table S2}

\section{Alleles generated in this study}

\begin{tabular}{|c|c|c|}
\hline Allele & Genotype & Information about mutagenesis \\
\hline ie121 & chk-2(ie121[HA::aid::chk-2]) & $\begin{array}{l}\text { generated using } d p y-10 \text { Co-CRISPR in ieSi38[sun-1p::tir1::mRuby::sun-1 } \\
\text { 3'UTR, Cbr-unc-119(+)] IV }\end{array}$ \\
\hline ie122 & him-8 (ie122) mutant & $\begin{array}{l}\text { generated using dpy-10 Co-CRISPR in meIs8[pie-1p::GFP::cosa-1, unc- } \\
\text { 119(+)] II; ieSi38[sun-1p::tir1::mRuby::sun-1 3'UTR, Cbr-unc-119(+)] IV; } \\
\text { chk-2(ie121[HA::aid::chk-2]) V }\end{array}$ \\
\hline ie123 & syp-1(ie123[syp-1 T452A]) & $\begin{array}{l}\text { generated using dpy-10 Co-CRISPR in plk-2(ie50[plk-2::mRuby] I; } \\
\text { meIs8[pie-1p::GFP::cosa-1, unc-119(+)] II }\end{array}$ \\
\hline ieSi64 & [gld-1p::tir1::mRuby::sun-1 3' UTR, Cbr-unc-119(+)] II & Single copy transgene inserted into Chr II (oxTi179) using mosSCI \\
\hline ie124 & $\cos a-1(i e 124[3 \times F L A G:: \cos a-1]$ & $\begin{array}{l}\text { generated using dpy-10 Co-CRISPR in ieSi64[gld-1p::tir1::mRuby::sun-1 3' } \\
\text { UTR, Cbr-unc-119(+)] II }\end{array}$ \\
\hline ie125 & plk-1(ie125[plk-1::aid::HA]) & $\begin{array}{l}\text { generated using dpy-10 Co-CRISPR in ieSi64[gld-1p::tir1::mRuby::sun-1 3' } \\
\text { UTR, Cbr-unc-119 (+)] II; cosa-1(ie124[3xFLAG::cosa-1] III }\end{array}$ \\
\hline ie126 & plk-2(ie126[plk-2::aid::HA]) & $\begin{array}{l}\text { generated using dpy-10 Co-CRISPR in ieSi64[gld-1p::tir1::mRuby::sun-1 3' } \\
\text { UTR, Cbr-unc-119 (+)] II; cosa-1(ie124[3xFLAG::cosa-1] III }\end{array}$ \\
\hline ie54 & mpk-1(ie54[aid::3xFLAG::mpk-1]) & $\begin{array}{l}\text { generated using dpy-10 Co-CRISPR in plk-2(ie50[plk-2::mRuby] I; } \\
\text { meIs8[pie-1p::GFP::cosa-1, unc-119(+)] II; ieSi38[sun-1p::tir1::mRuby::sun-1 } \\
\text { 3'UTR, Cbr-unc-119(+)] IV }\end{array}$ \\
\hline ie127 & chk-2(ie127[HA::chk-2]) & $\begin{array}{l}\text { generated using dpy-10 Co-CRISPR in meIs8[pie-1p::GFP::cosa-1, unc- } \\
\text { 119(+)] II; ieSi38[sun-1p::tir1::mRuby::sun-1 3' UTR, Cbr-unc-119(+)] IV }\end{array}$ \\
\hline ie128 & chk-2(ie128[HA::chk-2 S116A]) & $\begin{array}{l}\text { generated using dpy-10 Co-CRISPR in meIs8[pie-1p::GFP:::cosa-1, unc- } \\
\text { 119(+)] II; ieSi38[sun-1p::tir1::mRuby::sun-1 3' UTR, Cbr-unc-119(+)] IV; } \\
\text { chk-2(ie127[HA::chk-2]) }\end{array}$ \\
\hline ie129 & $\operatorname{chk}-2(i e 129[H A:: c h k-2 S 116 A])$ & $\begin{array}{l}\text { generated using dpy-10 Co-CRISPR in meIs8[pie-1p::GFP:::cosa-1, unc- } \\
\text { 119(+)] II; ieSi38[sun-1p::tir1::mRuby::sun-1 3' UTR, Cbr-unc-119(+)] IV; } \\
\text { chk-2(ie127[HA::chk-2]) }\end{array}$ \\
\hline ie130 & chk-2(ie130[HA::chk-2 S116D]) & $\begin{array}{l}\text { generated using dpy-10 Co-CRISPR in meIs8[pie-1p::GFP:::cosa-1, unc- } \\
\text { 119(+)] II; ieSi38[sun-1p::tir1::mRuby::sun-1 3' UTR, Cbr-unc-119(+)] IV; } \\
\text { chk-2(ie127[HA::chk-2]) }\end{array}$ \\
\hline ie131 & chk-2(ie131[HA::chk-2 T120A]) & $\begin{array}{l}\text { generated using dpy-10 Co-CRISPR in meIs8[pie-1p::GFP:::cosa-1, unc- } \\
\text { 119(+)] II; ieSi38[sun-1p::tir1::mRuby::sun-1 3' UTR, Cbr-unc-119(+)] IV; } \\
\text { chk-2(ie127[HA::chk-2]) }\end{array}$ \\
\hline ie132 & chk-2(ie132[HA::chk-2 T120A]) & $\begin{array}{l}\text { generated using dpy-10 Co-CRISPR in meIs8[pie-1p::GFP:::cosa-1, unc- } \\
\text { 119(+)] II; ieSi38[sun-1p::tir1::mRuby::sun-1 3' UTR, Cbr-unc-119(+)] IV; } \\
\text { chk-2(ie127[HA::chk-2]) }\end{array}$ \\
\hline ie133 & chk-2(ie133[HA::chk-2 T120D]) & $\begin{array}{l}\text { generated using dpy-10 Co-CRISPR in meIs8[pie-1p::GFP:::cosa-1, unc- } \\
\text { 119(+)] II; ieSi38[sun-1p::tir1::mRuby::sun-1 3' UTR, Cbr-unc-119(+)] IV; } \\
\text { chk-2(ie127[HA::chk-2]) }\end{array}$ \\
\hline ie134 & chk-2(ie134[HA::chk-2 T120D]) & $\begin{array}{l}\text { generated using dpy-10 Co-CRISPR in meIs8[pie-1p::GFP:::cosa-1, unc- } \\
\text { 119(+)] II; ieSi38[sun-1p::tir1::mRuby::sun-1 3' UTR, Cbr-unc-119(+)] IV; } \\
\text { chk-2(ie127[HA::chk-2]) }\end{array}$ \\
\hline ie135 & plk-3(ie135) mutant & $\begin{array}{l}\text { generated using dpy-10 Co-CRISPR in meIs8[pie-1p::GFP:::cosa-1, unc- } \\
\text { 119(+)] II; ieSi38[sun-1p::tir1::mRuby::sun-1 3' UTR, Cbr-unc-119(+)], him- } \\
\text { 8(ie122) IV; chk-2(ie121[HA::aid::chk-2]) V }\end{array}$ \\
\hline ie136 & plk-3(ie136) mutant & $\begin{array}{l}\text { generated using dpy-10 Co-CRISPR in plk-2(ie126[plk-2::aid::HA]) I; } \\
\text { ieSi64[gld-1p::tir1::mRuby::sun-1 3' UTR, Cbr-unc-119 (+)] II; cosa- } \\
\text { 1(ie124[3xFLAG::cosa-1], plk-1(ie125[plk-1::aid::HA]) III }\end{array}$ \\
\hline
\end{tabular}


bioRxiv preprint doi: https://doi.org/10.1101/2021.06.20.449183; this version posted June 21, 2021. The copyright holder for this preprint (which was not certified by peer review) is the author/funder. All rights reserved. No reuse allowed without permission.

\section{Supplemental Table S3}

\section{crRNAs, repair templates and genotyping primers used in this study}

\begin{tabular}{|c|c|c|}
\hline Transgenes & crRNAs and repair templates & Genotyping primers and fragment sizes \\
\hline $\begin{array}{l}\text { chk- } \\
\text { 2(ie121[HA::aid::chk- } \\
\text { 2]) }\end{array}$ & $\begin{array}{l}\text { 5'-TCTTTTTGTCCCGCGAACCA-3'; 5'- } \\
\text { attgaattttttgcgatttttggggcaaattttggtgattttttacTTTTCCGCCGAGCTCCGACGTCTc } \\
\text { TTgGTtCCaCGgACTCCTGAGCCTCCtttcacgaacgccgccgcctccgggccaccgcttgattttt } \\
\text { ggcaggaaaccatcacgttcttccggtatgatctcaccggtggccatcccacaacttgtgccttggccggaggtttggc } \\
\text { tggatctttaggcatCGATCCGGCATAATCTGGCACATCATATGGGTACATggaaatcg } \\
\text { ctgaaaaaatggagaaaattgcgaaaaaatggagaaaattgcgaaaaaaacgaag- 3' }\end{array}$ & $\begin{array}{l}\text { F: 5'-ctacggtagtttttaaaggcgcag-3'; R: 5'- } \\
\text { GATTCTCCGACGACAAGATCCTC-3'; } \\
\text { WT, 354bp; inserted, 534bp }\end{array}$ \\
\hline him-8 (ie122) & 5'-TATCGACGTGCTCTCGGTGA-3'; NA & $\mathrm{NA}$ \\
\hline $\begin{array}{l}\text { ieSi64 [gld- } \\
\text { 1p::tir1::mRuby::sun-1 } \\
\text { 3' UTR, Cbr-unc-119 } \\
(+)] I I\end{array}$ & NA; pLZ69 & $\begin{array}{l}\text { oxTi179_II_F: 5'- } \\
\text { TTGCCACGTCTTCTTGAGTG-3'; } \\
\text { oxTi179_II_R: 5'- } \\
\text { TGCTCGGAAGGACTTGATTT-3'. } \\
\text { WT, 281bp; inserted, >10kb }\end{array}$ \\
\hline $\begin{array}{l}\cos a- \\
\text { 1(ie124[3xFLAG:: } \cos a- \\
\text { 1]) }\end{array}$ & $\begin{array}{l}\text { 5'-aagtgtcaATGTCAAGTTCT-3'; 5'- } \\
\text { cgacaaaatcagtgaaaaatcgtgaaaactgaactgaagtgtcaATGGAtTAtAAaGACCAtGAtGG } \\
\text { AGAcTAtAAGGAtCACGAtATtGAtTACAAaGACGAtGAtGAtAAaggagctggatca } \\
\text { TCAAGTTCTCGgtgagttgtcgttcaaaataaaatgcgaacactgcctgtcaccatg- 3' }\end{array}$ & $\begin{array}{l}\text { F: 5'-cgtaaaccttcaaggcgcacag-3'; R: 5'- } \\
\text { CTGATACGGCAGGTGTACCTAGAG-3'; } \\
\text { WT, 310bp; inserted, 388bp }\end{array}$ \\
\hline $\begin{array}{l}\text { plk-1(ie125[plk- } \\
\text { 1::aid::HA]) }\end{array}$ & $\begin{array}{l}\text { 5'-acatacggatCTATCGACGT-3'; 5'- } \\
\text { GATATGCCACGGTCAATGGCAGCTGCTCGTTCAGCTTCGGCAGGATCACG } \\
\text { AGGACCAAATCAAGCTGCATCGCACCTTCCCCAGTCGGCAAGTGGATCCA } \\
\text { ATATTCACCCACGTCGAggagctggatcaCCTAAAGATCCAGCCAAACCTCCGG } \\
\text { CCAAGGCACAAGTTGTGGGATGGCCACCGGTGAGATCATACCGGAAGAA } \\
\text { CGTGATGGTTTCCTGCCAAAAATCAAGCGGTGGCCCGGAGGCGGCGGCGT } \\
\text { TCGTGAAGggagccggatctTACCCCTACGATGTCCCAGATTATGCTTAGatccgtat } \\
\text { gtgctctttgccacttccatgaatttgcttacatctcctgattaattccaagaagtattattctatacatttaacccgtactc } \\
\text { ttcatttattgttgctgtttttcatcgac- }\end{array}$ & $\begin{array}{l}\text { F: 5'- } \\
\text { cgtataatttacagAAATTCCTTCACCGAC-3'; } \\
\text { R: 5'-catcagtatttacaatgaaatgagctacg-3'; } \\
\text { WT, 433bp; inserted, 616bp }\end{array}$ \\
\hline $\begin{array}{l}\text { plk-2(ie126[plk- } \\
\text { 2::aid::HA]) }\end{array}$ & $\begin{array}{l}\text { 5'-tcgattttcTTAGCGACGCG-3'; 5'- } \\
\text { GAAAGAGGAGACGAAACACAATGCACCGGCGGCCAATGCAGTACGCCTT } \\
\text { CCATCGACTTCCAGCAACGTCCGTTTGGAATCTGCAGCAGATATCCAGCC } \\
\text { GGCTTATCCATCATCCTCGCGTCGCggagctggatcaCCTAAAGATCCAGCCAA } \\
\text { ACCTCCGGCCAAGGCACAAGTTGTGGGATGGCCACCGGTGAGATCATACC } \\
\text { GGAAGAACGTGATGGTTTCCTGCCAAAAATCAAGCGGTGGCCCGGAGGC } \\
\text { GGCGGCGTTCGTGAAGggagccggatctTACCCCTACGATGTCCCAGATTATGC } \\
\text { TTAAgaaaatcgatctgcaacaaattgagctcatttccccttaccggttttgatatttctctgatcaatacacttttatg } \\
\text { tccgtgtttgtaatcaattttatcc- 3' }\end{array}$ & $\begin{array}{l}\text { F: 5'-GGAGAAGTTCCTCCATCGAATTC- } \\
\text { 3'; R: 5'-gagcatgatgacacccgaatgtttg-3'; } \\
\text { WT, 451bp; inserted, 634bp }\end{array}$ \\
\hline $\begin{array}{l}\text { mpk- } \\
\text { 1(ie54[aid::3xFLAG::mp } \\
k-1])\end{array}$ & $\begin{array}{l}\text { 5'-TAAATACTACTAATCTAAAC-3'; 5'- } \\
\text { GCGGCTGCAAGGAATAATGGAGGGCAGAATCCTGTTGGAGCTGGATCAA } \\
\text { TGCCTAAAGATCCAGCCAAACCTCCGGCCAAGGCACAAGTTGTGGGATG } \\
\text { GCCACCGGTGAGATCTTACCGGAAGAACGTGATGGTTTCCTGCCAAAAAT } \\
\text { CAAGCGGTGGCCCGGAGGCGGCGGCGTTCGTGAAGGGAGCCGGATCTGA } \\
\text { TTATAAAGACCATGATGGAGACTATAAGGATCACGATATTGATTACAAA } \\
\text { GACGATGATGATAAATAATAGATTAGTAGTATTTACCCACTAAATTAGTT } \\
\text { ATTTTTTCCACTTTTTTTTTATTTTCCACTAAGATTTTGGCATTTCAGTTTC } \\
\text { TTTTTCGATGTATCATAATCCACTTCAAAACTCGATCG- 3' }\end{array}$ & $\begin{array}{l}\text { F: 5'- } \\
\text { CAGTTTGTGAGGAACCATTCACTTTGG } \\
\text {-3'; R: 5'-gagtgattaattggaggaggtgcattc-3'; } \\
\text { WT, 426bp; inserted, 654bp }\end{array}$ \\
\hline $\begin{array}{l}\text { chk-2(ie127[HA::chk- } \\
\text { 2]) }\end{array}$ & $\begin{array}{l}\text { 5'-tcagcgatttccATGGTTCG-3'; 5'- } \\
\text { ccatttttcgcaattttctccattttttcagcgatttccATGTACCCATATGATGTGCCAGATTAT } \\
\text { GCCGGAGGCTCAGGAGTTCGCGGGACAAAAAGACGTCGGAGCTCGGCGG } \\
\text { AAAAgtaaaaaatcac- 3' }\end{array}$ & $\begin{array}{l}\text { F: 5'-gtctcgccgcgattttcgtattttc-3'; R: 5'- } \\
\text { CAAGCTTCGCGAAGGGTTTTGAAG-3'; } \\
\text { WT, 339bp; inserted, 378bp }\end{array}$ \\
\hline $\begin{array}{l}\text { chk-2(ie128[HA::chk-2 } \\
\text { S116A]) and chk- } \\
\text { 2(ie129[HA::chk-2 } \\
\text { S116A]) }\end{array}$ & $\begin{array}{l}\text { 5'-TACACGATCACTCACGCAAC-3'; 5'- } \\
\text { caatatttcagGACACAGAAACGCGTAGAATCTATCTACACGATCACgCcCGCA } \\
\text { ACGGaACCCTCGTAAATCAGGAAATGATCGGAAAAGGGCTGTCCAGAGA } \\
\text { G- 3' }\end{array}$ & $\begin{array}{l}\text { F: 5'-gattttccagACTTGGCAGACGATC-3'; } \\
\text { R: 5'-cgtcaaaaacgcacTGATCAGCGCTG-3'; } \\
\text { WT, 337bp; mutant, 337bp=223bp+114bp } \\
\text { (Cac8I digestion) }\end{array}$ \\
\hline $\begin{array}{l}\text { chk-2(ie130[HA::chk-2 } \\
\text { S116D]) }\end{array}$ & $\begin{array}{l}\text { 5'-TACACGATCACTCACGCAAC-3'; 5'- } \\
\text { caatatttcagGACACAGAAACGCGTAGAATCTATCTACACGATCACgatCGCAA } \\
\text { CGGaACCCTCGTAAATCAGGAAATGATCGGAAAAGGGCTGTCCAGAGAG- } \\
\text { 3' }\end{array}$ & $\begin{array}{l}\text { F: 5'-gattttccagACTTGGCAGACGATC-3'; } \\
\text { R: 5'-cgtcaaaaacgcacTGATCAGCGCTG-3'; } \\
\text { WT, 337bp; mutant, 337bp=223bp+114bp } \\
\text { (PvuI digestion) }\end{array}$ \\
\hline $\begin{array}{l}\text { chk-2(ie131[HA:: chk-2 } \\
\text { T120A]) and chk- } \\
\text { 2(ie132[HA::chk-2 } \\
\text { T120A]) }\end{array}$ & $\begin{array}{l}\text { 5'-CGATCATTTCCTGATTTACG-3'; 5'- } \\
\text { CTCCGTTCATTAGCTCTCTGGACAGCCCTTTTCCGATCATTTCCTGATTTA } \\
\text { CGAGaGctCCGTTGCGTGAGTGATCGTGTAGATAGATTCTACGCGTTTCTG } \\
\text { TGTCctgaaatattg- 3' }\end{array}$ & $\begin{array}{l}\text { F: 5'-gattttccagACTTGGCAGACGATC-3'; } \\
\text { R: 5'-cgtcaaaaacgcacTGATCAGCGCTG-3'; } \\
\text { WT, 337bp; mutant, 337bp=233bp+104bp } \\
\text { (SacI digestion) }\end{array}$ \\
\hline
\end{tabular}


bioRxiv preprint doi: https://doi.org/10.1101/2021.06.20.449183; this version posted June 21, 2021. The copyright holder for this preprint (which was not certified by peer review) is the author/funder. All rights reserved. No reuse allowed without permission.

\begin{tabular}{|c|c|c|}
\hline $\begin{array}{l}\text { chk-2(ie133[HA::chk-2 } \\
\text { T120D]) and chk- } \\
\text { 2(ie134[HA::chk-2 } \\
\text { T120D]) }\end{array}$ & $\begin{array}{l}\text { 5'-CGATCATTTCCTGATTTACG-3'; 5'- } \\
\text { CTCTCTGGACAGCCCTTTTCCGATCATTTCCTGATTTACGAGatcCCCGTTG } \\
\text { CGTGAGTGATCGTGTAGATAGATTCTACGCGTTTCTGTGTCctgaaatattg- 3' }\end{array}$ & $\begin{array}{l}\text { F: 5'-gattttccagACTTGGCAGACGATC-3'; } \\
\text { R: 5'-cgtcaaaaacgcacTGATCAGCGCTG-3'; } \\
\text { WT, 337bp; mutant, 337bp=234bp+103bp } \\
\text { (XhoII digestion) }\end{array}$ \\
\hline $\begin{array}{l}\text { plk-3 (ie135) and plk-3 } \\
\text { (ie136) }\end{array}$ & $\begin{array}{l}\text { 5'-GCTCCGTACTCGCGGAAACT-3'; 5'- } \\
\text { caaatttattcatcgtttctagATGCAGCATGTGCTCCGTACTCGCGGAAACTAAGCTC } \\
\text { GAGTCGGCACAAGATAAAAATAAAAAGCATGTTCCTAATGTACCGCCAA } \\
\text { TTATCTAC- } 3 \text { ' }\end{array}$ & $\begin{array}{l}\text { F: 5'-caacgtgtttagttgaattgcacttc-3'; R: 5'- } \\
\text { CTGTCGATGAATTTCAACTTCTCGAG- } \\
\text { 3'; } \\
\text { WT, 380bp; mutant, 390bp=150bp+240bp } \\
\text { (Xhol digestion) }\end{array}$ \\
\hline
\end{tabular}


bioRxiv preprint doi: https://doi.org/10.1101/2021.06.20.449183; this version posted June 21, 2021. The copyright holder for this preprint (which was not certified by peer review) is the author/funder. All rights reserved. No reuse allowed without permission.

\section{Supplemental Table S4}

\section{Site directed mutagenesis and colony PCR Primers}

\begin{tabular}{|c|c|c|}
\hline Primer & Sequence & Purpose \\
\hline $\begin{array}{l}\text { mek1- } \\
\text { S91A- } \\
\text { T95A- } \\
\text { F }\end{array}$ & 5'CCAATGTTCTACGTTAAAGATTGTgCaCTTAATGGAgctTATTTGAACGGTTTGCTTTTGAAAAGGG & $\begin{array}{l}\text { Used with mek1-S91A- } \\
\text { T95A-R to create } \\
\text { mek1-2A on pLP37 }\end{array}$ \\
\hline $\begin{array}{l}\text { mek1- } \\
\text { S91A- } \\
\text { T95A- } \\
\text { R }\end{array}$ & 5'CCCTTTTCAAAAGCAAACCGTTCAAATAagcTCCATTAAGtGcACAATCTTTAACGTAGAACATTGG & $\begin{array}{l}\text { Used with mek1-S91A- } \\
\text { T95A-F to create } \\
\text { mek1-2A on pLP37 }\end{array}$ \\
\hline $\begin{array}{l}\text { mek1- } \\
\text { S91D- } \\
\text { T95D- } \\
\text { F }\end{array}$ & 5'CCAATGTTCTACGTTAAAGATTGTgatCTTAATGGAgacTATTTGAACGGTTTGCTTTTGAAAAGGG & $\begin{array}{l}\text { Used with mek1-S91D- } \\
\text { T95D-R to create } \\
\text { mek1-2D on pLP37 }\end{array}$ \\
\hline $\begin{array}{l}\text { mek1- } \\
\text { S91D- } \\
\text { T95D- } \\
\mathrm{R}\end{array}$ & 5'CCCTTTTCAAAAGCAAACCGTTCAAATAgtcTCCATTAAGatcACAATCTTTAACGTAGAACATTGG & $\begin{array}{l}\text { Used with mek1-S91D- } \\
\text { T95D-F to create } \\
\text { mek1-2D on pLP37 }\end{array}$ \\
\hline $\begin{array}{l}\text { mek1- } \\
\text { S91E- } \\
\text { T95E-F }\end{array}$ & 5' CCAATGTTCTACGTTAAAGATTGTgaaCTTAATGGAgagTATTTGAACGGTTTGCTTTTGAAAAGGG & $\begin{array}{l}\text { Used with mek1-S91E- } \\
\text { T95E-R to create } \\
\text { mek } 1-2 E \text { on pLP37 }\end{array}$ \\
\hline $\begin{array}{l}\text { mek1- } \\
\text { S91E- } \\
\text { T95E- } \\
\text { R } \\
\end{array}$ & 5' CCCTTTTCAAAAGCAAACCGTTCAAATActcTCCATTAAGttcACAATCTTTAACGTAGAACATTGG & $\begin{array}{l}\text { Used with mek1-S91E- } \\
\text { T95E-F to create } \\
\text { mek1-2E on pLP37 }\end{array}$ \\
\hline $\begin{array}{l}\text { mek1- } \\
\text { S91A-F }\end{array}$ & 5' CCAATGTTCTACGTTAAAGATTGTgCaCTTAATGGAACGTATTTGAACGG & $\begin{array}{l}\text { Used with mek1-S91A- } \\
\mathrm{R} \text { to create mek1-S91A } \\
\text { on pLP37 }\end{array}$ \\
\hline $\begin{array}{l}\text { mek1- } \\
\text { S91A- } \\
\text { R }\end{array}$ & 5’ CCGTTCAAATACGTTCCATTAAGtGcACAATCTTTAACGTAGAACATTGG & $\begin{array}{l}\text { Used with mek1-S91A- } \\
\text { F to create mek1-S91A } \\
\text { on pLP37 }\end{array}$ \\
\hline $\begin{array}{l}\text { mek1- } \\
\text { S91D-F }\end{array}$ & 5' CCAATGTTCTACGTTAAAGATTGTgatCTTAATGGAACGTATTTGAACGG & $\begin{array}{l}\text { Used with mek1-S91D- } \\
\mathrm{R} \text { to create mek1-S91D } \\
\text { on pLP37 }\end{array}$ \\
\hline $\begin{array}{l}\text { mek1- } \\
\text { S91D- } \\
\text { R }\end{array}$ & 5' CCGTTCAAATACGTTCCATTAAGatcACAATCTTTAACGTAGAACATTGG & $\begin{array}{l}\text { Used with mek1-S91D- } \\
\mathrm{F} \text { to create mek1-S91D } \\
\text { on pLP37 }\end{array}$ \\
\hline $\begin{array}{l}\text { mek1- } \\
\text { S91E-F }\end{array}$ & 5' CCAATGTTCTACGTTAAAGATTGTgaaCTTAATGGAACGTATTTGAACGG & $\begin{array}{l}\text { Used with mek1-S91E- } \\
\mathrm{R} \text { to create mek1-S91E } \\
\text { on pLP37 }\end{array}$ \\
\hline $\begin{array}{l}\text { mek1- } \\
\text { S91E-R }\end{array}$ & 5' CCGTTCAAATACGTTCCATTAAGttcACAATCTTTAACGTAGAACATTGG & $\begin{array}{l}\text { Used with mek1-S91E- } \\
\text { F to create mek1-S91E } \\
\text { on pLP37 }\end{array}$ \\
\hline $\begin{array}{l}\text { mek1- } \\
\text { T95A- } \\
\text { F }\end{array}$ & 5’ GATTGTTCTCTTAATGGAgctTATTTGAACGGTTTGCTTTTGAAAAGGG & $\begin{array}{l}\text { Used with mek1- } \\
\text { T95A-R to create } \\
\text { mek1-T95A on pLP37 }\end{array}$ \\
\hline $\begin{array}{l}\text { mek1- } \\
\text { T95A- } \\
\mathrm{R}\end{array}$ & 5' CCCTTTTCAAAAGCAAACCGTTCAAATAagcTCCATTAAGAGAACAATC & $\begin{array}{l}\text { Used with mek1- } \\
\text { T95A-F to create } \\
\text { mek1-T95A on pLP37 }\end{array}$ \\
\hline $\begin{array}{l}\text { mek1- } \\
\text { T95D- } \\
\text { F }\end{array}$ & 5' GATTGTTCTCTTAATGGAgacTATTTGAACGGTTTGCTTTTGAAAAGGG & $\begin{array}{l}\text { Used with mek1- } \\
\text { T95D-R to create } \\
\text { mek1-T95D on pLP37 }\end{array}$ \\
\hline $\begin{array}{l}\text { mek1- } \\
\text { T95D- } \\
\mathrm{R}\end{array}$ & 5' CCCTTTTCAAAAGCAAACCGTTCAAATAgtcTCCATTAAGAGAACAATC & $\begin{array}{l}\text { Used with mek1- } \\
\text { T95A-F to create } \\
\text { mek1-T95A on pLP37 }\end{array}$ \\
\hline $\begin{array}{l}\text { mek1- } \\
\text { T95E-F }\end{array}$ & 5' GATTGTTCTCTTAATGGAgaGTATTTGAACGGTTTGCTTTTGAAAAGGG & $\begin{array}{l}\text { Used with mek1-T95E- } \\
\text { R to create mek1-T95E } \\
\text { on pLP37 }\end{array}$ \\
\hline $\begin{array}{l}\text { mek1- } \\
\text { T95E- } \\
\text { R }\end{array}$ & 5' CCCTTTTCAAAAGCAAACCGTTCAAATACtcTCCATTAAGAGAACAATC & $\begin{array}{l}\text { Used with mek1-T95E- } \\
\text { F to create mek1-T95E } \\
\text { on pLP37 }\end{array}$ \\
\hline $\begin{array}{l}\text { MEK1- } \\
\text { OUT }\end{array}$ & 5’ ATGATGGCGGCTAAATTTCGGCGG & $\begin{array}{l}\text { Used with MEK1- } \\
\text { SEQ14 to confirm }\end{array}$ \\
\hline
\end{tabular}


bioRxiv preprint doi: https://doi.org/10.1101/2021.06.20.449183; this version posted June 21, 2021. The copyright holder for this preprint (which was not certified by peer review) is the author/funder. All rights reserved. No reuse allowed without permission.

\begin{tabular}{|c|c|c|}
\hline & & $\begin{array}{l}\text { presence of mek1 } \\
\text { plasmid with colony } \\
\text { PCR }\end{array}$ \\
\hline $\begin{array}{l}\text { MEK1- } \\
\text { SEQ14 }\end{array}$ & 5' CTTCACTTCCCTGCGATAATTC & $\begin{array}{l}\text { Used with MEK1-OUT } \\
\text { to confirm presence of } \\
\text { mek1 plasmid with } \\
\text { colony PCR }\end{array}$ \\
\hline $\begin{array}{l}\text { pCLB2 } \\
- \\
\text { CDC5- } \\
\text { F4 }\end{array}$ & 5'TCTCATTCATTCATCGATAAACGTTACATTTGTTATTCATAGAGAATAAAgaaTTCGAGCTCGTTTAAAC & $\begin{array}{l}\text { Used with pCLB2- } \\
\text { CDC5-R4 to PCR } \\
\text { amplify } \\
\text { kanMX6::pCLB2::CDC } \\
5 \text { from pMJ787 }\end{array}$ \\
\hline $\begin{array}{l}\text { pCLB2 } \\
- \\
\text { CDC5- } \\
\text { R4 }\end{array}$ & $\begin{array}{l}\text { 5'CGGGTATTCAATTGCTTATCATTGATAGCTTTAAGAGGACCCAACGACATAAAGATGttaattaaGgacatCTATAA } \\
\text { G }\end{array}$ & $\begin{array}{l}\text { Used with pCLB2- } \\
\text { CDC5-F4 to PCR } \\
\text { amplify } \\
\text { kanMX6::pCLB2::CDC } \\
5 \text { from pMJ787 }\end{array}$ \\
\hline
\end{tabular}

